\title{
“OVERCOMING INHUMAN DIFFICULTIES": I.V. STALIN CRIMEAN STATE MEDICAL INSTITUTE IN THE PERIOD OF THE GREAT PATRIOTIC WAR (ACCORDING TO DOCUMENTS FROM THE STATE ARCHIVE OF THE RUSSIAN FEDERATION) ${ }^{1}$
}

\author{
Andrey A. Nepomnyashchiy \\ V.I. Vernadsky Crimean Federal University, Simferopol, Russian Federation; \\ Crimean Scientific Center of Sh. Marjani Institute of History of the Tatarstan Academy of Sciences, \\ Bakhchisaray, Russian Federation \\ Dmitriy A. Lomakin \\ V.I. Vernadsky Crimean Federal University, Simferopol, Russian Federation
}

\begin{abstract}
Introduction. The article focuses mainly on the activities of I.V. Stalin Crimean State Medical Institute during the Great Patriotic War, its main areas of work. Comprehensive scientific developments on this issue are not available in Russian historiography. Methods and materials. The research is carried out based on a variety of archival sources from the funds of the State Archive of the Russian Federation (SARF, Moscow), which are introduced into scientific discourse for the first time. Various groups of documents are widely involved: correspondence of S.R. Tatevosov, director of the institute, with the authorities on the functioning of the university; directives, decrees of state institutions reflected in the activities of the medical institute; university reporting and planning documentation. Analysis. Employees and students of Crimean Medical Institute were forced to leave the peninsula after the outbreak of the Great Patriotic War, from the moment of the threat of occupation of the Crimea. The university team had to be evacuated along the route: Armavir - Tbilisi Krasnovodsk - Dzhambul - again Armavir - Ordzhonikidze - Baku - Krasnovodsk - Kzyl-Orda. Their wanderings lasted almost a year, however, the university did not stop its activities for a single day as the front was in dire need of medical specialists. Two turnouts graduated in Kzyl-Orda in incredibly difficult conditions. In total, from June 1941 to July 1944, the institute trained 850 doctors, wherefore the university staff was awarded with personal thanks of I.V. Stalin. Results. The heroic history of I.V. Stalin Crimean State Medical Institute during the Great Patriotic War has been restored. The activity of lecturers of the institute during the period of forced evacuation to the territory of the Kazakh Soviet Socialist Republic (the city of Kzyl-Orda) has been analyzed. The stage of resuming the work of the university after its re-evacuation to Simferopol has been recreated in detail, the measures taken to prepare for the beginning of the first academic year in the Crimea in the autumn of 1944 have been restored. In order to prepare the study, the authors have carried out a detailed historiographic i analysis, and have selected the source base carefully.

तิ Key words: I.V. Stalin Crimean State Medical Institute, Great Patriotic War, evacuation, Kazakh SSR, Kzyl-Orda.

Citation. Nepomnyashchiy A.A., Lomakin D.A. "Overcoming Inhuman Difficulties": I.V. Stalin Crimean State Medical Institute in the Period of the Great Patriotic War (According to Documents from the State Archive of the Russian Federation). Vestnik Volgogradskogo gosudarstvennogo universiteta. Seriya 4. Istoriya. Regionovedenie. $\therefore$ Mezhdunarodnye otnosheniya [Science Journal of Volgograd State University. History. Area Studies. International \& Relations], 2020, vol. 25, no. 2, pp. 103-127. (in Russian). DOI: https://doi.org/10.15688/jvolsu4.2020.2.8
\end{abstract}




\title{
«ПРЕОДОЛЕВАЯ НЕЧЕЛОВЕЧЕСКИЕ ТРУДНОСТИ»: КРЫМСКИЙ ГОСУДАРСТВЕННЫЙ МЕДИЦИНСКИЙ ИНСТИТУТ ИМЕНИ И.В. СТАЛИНА В ГОДЫ ВЕЛИКОЙ ОТЕЧЕСТВЕННОЙ ВОЙНЫ (ПО ДОКУМЕНТАМ ИЗ ГОСУДАРСТВЕННОГО АРХИВА РОССИЙСКОЙ ФЕДЕРАЦИИ) ${ }^{1}$
}

\author{
Андрей Анатольевич Непомнящий \\ Крымский федеральный университет им. В.И. Вернадского, г. Симферополь, Российская Федерация; \\ Крымский научный центр Института истории им. Ш. Марджани АН Республики Татарстан, \\ г. Бахчисарай, Российская Федерация \\ Дмитрий Анатольевич Ломакин \\ Крымский федеральный университет им. В.И. Вернадского, г. Симферополь, Российская Федерация
}

Аннотация. Введение. Цель работы - проанализировать деятельность Крымского государственного медицинского института имени И.В. Сталина в годы Великой Отечественной войны, выявить основные направления работы вуза. Комплексные научные разработки по данному вопросу отсутствуют в отечественной историографии. Методы и материальl. Исследование выполнено на основе разнообразных архивных источников из фондов Государственного архива Российской Федерации (ГАРФ, г. Москва), которые впервые вводятся в научный оборот. Широко привлечены различные группы документов: переписка директора института С.Р. Татевосова с органами власти по вопросам функционирования вуза; директивы, постановления государственных учреждений, отразившиеся на деятельности мединститута; отчетно-плановая документация вуза. Анализ. После начала Великой Отечественной войны с момента возникновения угрозы оккупации Крыма сотрудники и студенты Крымского мединститута были вынуждены покинуть полуостров. Коллективу вуза пришлось эвакуироваться по маршруту: Армавир - Тбилиси - Красноводск - Джамбул - вновь Армавир - Орджоникидзе - Баку - Красноводск - Кзыл-Орда. Скитания длились почти год, тем не менее вуз ни на один день не прекращал своей деятельности - фронт остро нуждался в специалистах-медиках. В Кзыл-Орде, в невероятно трудных условиях, состоялось два выпуска специалистов. Всего с июня 1941 по июль 1944 г. институт подготовил 850 врачей, за что коллектив вуза был удостоен личной благодарности И.В. Сталина. Результаты. Восстановлена героическая история Крымского государственного медицинского института имени И.В. Сталина в годы Великой Отечественной войны. Проанализирована деятельность преподавателей института в период вынужденной эвакуации на территорию Казахской ССР (г. Кзыл-Орда). Детально воссоздан этап возобновления работы вуза после его реэвакуации в г. Симферополь, восстановлены проводимые мероприятия по подготовке к началу первого учебного года в Крыму осенью 1944 года.

Ключевые слова: Крымский государственный медицинский институт имени И.В. Сталина, Великая Отечественная война, эвакуация, Казахская ССР, Кзыл-Орда.

Цитирование. Непомнящий А. А., Ломакин Д. А. «Преодолевая нечеловеческие трудности»: Крымский государственный медицинский институт имени И.В. Сталина в годы Великой Отечественной войны (по документам из Государственного архива Российской Федерации) // Вестник Волгоградского государственного университета. Серия 4, История. Регионоведение. Международные отношения. -2020 . - Т. 25 , № 2. -C. 103-127. - DOI: https://doi.org/10.15688/jvolsu4.2020.2.8

Введение. Великая Отечественная война кардинальным образом отразилась на развитии высшего образования в Крыму, на долгие годы замедлив его, а в отдельных отраслях - отбросив существенно назад. К началу боевых действий на полуострове функционировало три высших учебных заведения (педагогический, медицинский и сельскохозяйственный институты), каждым из которых во время войны была написана своя уникальная, бесконечно героическая страница истории. Лишь благодаря титаническим усилиям сотрудников вузов ни один из них не прекратил свою работу, с честью пройдя нелегкие ис- 
пытания военного времени. Особая роль среди них принадлежала Крымскому медицинскому институту имени И.В. Сталина ${ }^{2}-$ вузу, готовившему в ряды Красной Армии квалифицированные медицинские кадры, столь важные и необходимые для Великой Победы.

Методы и материалы. Источниковую базу научной работы составил обширный комплекс архивных материалов из фондов Государственного архива Российской Федерации (ГАРФ, г. Москва), которые впервые вводятся в научный оборот. Использованы разнообразные группы выявленных документов: отчетно-плановая документация вуза; директивы, постановления государственных учреждений, отразившиеся на деятельности Крымского мединститута; переписка директора вуза С.Р. Татевосова с органами власти по вопросам функционирования учебного заведения; материалы проверок контролирующими органами учебного заведения на предмет его готовности к проведению учебных занятий в рассматриваемый период. Теоретико-методологическую основу исследования составили принципы историзма, научной объективности, системности. Задачи исследования решены путем сочетания общенаучных, специальноисторических и междисциплинарных методов. Применение такого методологического комплекса позволило всесторонне исследовать заявленную проблему.

Обсуждение. Поставленная в статье проблема не нашла полного отражения в историографии. Период работы вуза в эвакуации не освещен в подготовленном к 85-летию Медицинской академии КФУ сводном очерке, где основное внимание уделено научным школам, а работа в 1941-1945 гг. упомянута вскользь, порой без указания преподавателей [3]. Только упоминания о работе института в годы Великой Отечественной войны содержатся в справочнике «Профессора Медицинской академии им. С.И. Георгиевского ФГАОУ ВО “КФУ им. В.И. Вернадского", 1918-2016», подготовленном силами сотрудников академии [15]. Впервые история вуза в эвакуации была частично воссоздана в обобщающем фундаментальном труде, написанном к 100-летию открытия первого крымского университета, где военный период мытарств медиков кратко показан на фоне исто- рии эвакуации других крымских вузов [9, c. 120-124]. Отдельные фрагменты участия профессоров Крымского медицинского института им. И.В. Сталина в эвакуационных мероприятиях раскрыты в очерках трехтомного научного издания «Профессора Крымского федерального университета им. В.И. Вернадского» [12-14]. Информацию об этом сложном периоде дополняют опубликованные воспоминания профессоров института о военном периоде $[1 ; 2 ; 4]$. Таким образом, в научной литературе не восстановлена история вуза в годы Великой Отечественной войны.

Анализ. Крымский мединститут 19 сентября 1941 г. эвакуирован из Симферополя в Краснодарский край. По указанию краевых организаций вуз был направлен в Армавир, куда прибыл 26 сентября 1941 года [9, с. 120]. Благодаря тому, что была эвакуирована большая часть научного оборудования и учебных пособий (четыре вагона имущества), институту удалось возобновить работу в Армавиpe 29 сентября. Деятельность Крымского государственного медицинского института имени И.В. Сталина в Краснодарском крае в первые месяцы Великой Отечественной войны восстановлена на основе докладной записки его директора С.P. Татевосова в Народный комиссариат здравоохранения СССР (Наркомздрав) заместителю Народного комиссара здравоохранения СССР С.И. Миловидову от 18 февраля 1942 г.: «Работа проходила в исключительно тяжелых условиях. Институту были предоставлены одна школа на десять комнат и помещение медицинской школы во вторую смену. Из-за отсутствия твердого инвентаря - столов, стульев и прочего - теоретические кафедры полностью развернуть свою работу не смогли, тем не менее, были налажены на этих кафедрах не только теоретические, но и практические занятия. Клинические кафедры были размещены на соответствующих базах госпиталей и городских лечебных учреждений» [6, л. 30].

Серьезные трудности бытового характера возникли у коллектива института и студентов, не хватало жилых помещений: «Достаточно указать, что до двадцати человек <...> с семьями в течение двух месяцев находились в одной необорудованной комнате санпросвета. Студенты были размещены по ча- 
стным квартирам и платили за угол от 30 руб. в месяц» [6, л. 30]. Ограничивала возможности учебного заведения возникшая в условиях военного времени путаница с финансированием вуза: в течение сентября - ноября 1941 г. кредиты еще не были открыты институту, а открытые в Симферополе, в Армавир не были переведены. Это вызвало перебои с выплатой заработных плат и стипендий. Был организован фонд из собранных от профессоров средств для особо нуждающихся [6, л. 30-31]. Вузу, оказавшемуся в сложной ситуации, была оказана помощь местных властей: сотрудников и студентов института прикрепили к городской столовой, что дало им возможность питаться по сниженным ценам, институт был включен в плановое снабжение топливом, горючими и хозяйственными материалами [6, л. 31].

Находясь в прифронтовой полосе, Крымский государственный медицинский институт имени И.В. Сталина, не располагая даже минимальным количеством необходимых помещений, испытывая постоянные трудности с финансированием, не имея возможности наладить быт профессорско-преподавательского состава и студентов, лишился возможности продолжать образовательную деятельность. Когда единственное учебное помещение, в котором размещались все теоретические кафедры, было превращено в пересыльный пункт для красноармейцев, а госпиталя начали эвакуироваться из Армавира, «то стало совершенно ясно, что дальше продолжать свою работу институт не может» [6, л. 31]. С.Р. Татевосовым было принято решение самостоятельно, без специального распоряжения Народного комиссариата здравоохранения СССР, искать возможные пути эвакуации вуза. Предвидя необходимость эвакуации из Армавира, администрация института в течение двух месяцев отправляла запросы в Дагестанскую, Азербайджанскую, Грузинскую, Армянскую, Туркменскую и Казахскую Республики с просьбой о размещении вуза, докладные записки в различные инстанции с изложением критического положения дел, однако никаких указаний, а тем более конкретной помощи институт не получил. Из Комитета обороны Армавира и городского исполнительного комитета возражений про- тив выезда института из Армавира не последовало. Штаб Северо-Кавказского военного округа счел, что вуз продолжать работу в городе не может, и отдал распоряжение местной железной дороге предоставить институту транспорт. В НКВД Армавира был выдал пропуск на выезд коллектива учебного заведения в Баку. Институт покинул Армавир в конце ноября 1941 г. с надеждой хотя бы о временном размещении в одном из городов Казахской ССР, Дагестанской ССР или Закавказья [6, л. 30-31].

В Махачкале уполномоченный по эвакуации тов. Лукишев выдал институту направление в Грузинскую ССР [6, л. 28]. 6 декабря 1941 г. вуз прибыл в Тбилиси, где в работе ему было категорически отказано. Кроме того, поступило предложение о расформировании института. Лишь благодаря решительной позиции коллектива преподавателей во главе с директором учебного заведения медицинский институт удалось сохранить. Прибыв на станцию Навтлуги, коллектив вуза был встречен представителями грузинского Правительства. От имени ЦК ВКП(б) и СНК Грузии было предложено распустить институт, использовать студентов в качестве рабочих на строительстве железной дороги «Боржоми», а профессорско-преподавательский состав, по возможности, использовать по специальности в районах. Коллектив института нашел невозможным выполнить это предложение [6, л. 30-31].

В декабре 1941 г. - январе 1942 г., когда на фронтах Великой Отечественной войны Красная Армия продолжала нести существенные потери и возникла реальная угроза захвата немецкими войсками Москвы, в условиях нарастающей паники, зачастую несогласованных необдуманных действий и распоряжений правительства, судьба Крымского мединститута окончательно не была решена. В первой половине декабря 1941 г. Крымский мединститут был выслан из г. Тбилиси и направлен в г. Алма-Ату Казахской ССР через г. Баку, куда институт прибыл 10 декабря. Без специальных распоряжений Советского Правительства по настоянию руководства АзССР 12 декабря коллектив погрузили на пароход и выслали в г. Красноводск для дальнейшего следования в Ка- 
захскую ССР. На железнодорожной станции Арысь уполномоченный по эвакуации по Казахской ССР тов. Нечитайло сообщил, что в Казахской ССР институт не примут и направил вуз в г. Новосибирск. На станции Джамбул коллектив получил сообщение от Красноводского областного исполнительного комитета о том, что по распоряжению СНК СССР, СНК АзССР возвращает Крымский мединститут для размещения в г. Баку, куда институт прибыл 1 января 1942 года [6, л. 31].

Дальнейшие сведения о мытарствах коллектива Крымского мединститута в конце 1941 г. содержит письмо старшего инспектора Главного управления медицинскими учебными заведениями Наркомздрава СССР П. Колосова Народному комиссару здравоохранения СССР Г.А. Митереву от 20 февраля 1942 г.: «В Баку дирекция института получила два распоряжения: 1. От 16 декабря 1941 года СНК СССР о размещении института в Баку; 2. Телеграмму за подписью тов. Шверника от 18 декабря 1941 г. с указанием о возвращении института в Армавир и привлечении директора к ответственности. 1 января 1942 года институт получил телеграмму от заместителя Наркомздрава СССР тов. Миловидова о размещении Крымского института в Баку. Зам. Председателя СНК АзССР тов. Аллахвердиев, получив вышеуказанные распоряжения СНК СССР т. Шверника, предложил институту выехать в Армавир <... $>$. На распоряжении СНК СССР зам. председателя СНК Азербайджанской ССР тов. Аллахвердиев наложил резолюцию "А разве они еще не уехали, институт выехал в Армавир" <... . Кредиты же институту открыты в Баку» [6, л. 2829]. В январе 1942 г. коллектив Крыммединститута был вынужден вернуться в Армавир. Вузу было предоставлено под учебный корпус только одно помещение, состоящее из десяти комнат. Несмотря на тяжелые условия, институт возобновил работу [6, л. 31].

15 июля 1942 г. С.Р. Татевосовым составлена докладная записка «Крымский медицинский институт имени И.В. Сталина за год войны», во многом прояснившая положение вуза и его сотрудников после возвращения в Армавир [6, л. 8]. Из нее следует, что на 22 июня 1942 г. в институте числилось 708 студентов. В феврале - марте 1942 г. вуз по собственной инициативе провел зимний набор. Весь профессорско-преподавательский состав, за исключением призванных в ряды Красной Армии и оставленных Правительством Крымской АССР для обслуживания местных лечебных учреждений, эвакуированный из Симферополя, продолжил работу в институте. На освободившиеся ставки выбывших профессоров были приглашены квалифицированные специалисты из других вузов. Была организована научная библиотека за счет привезенных из Крыма пособий. На кафедрах открыты студенческие кружки, функционировало студенческое научное общество. Институту удалось оборудовать лаборатории, виварий, имелось минимальное количество необходимых реактивов. В учебных целях использовались лечебно-профилактические учреждения города, госпитали. За год войны Крымский медицинский институт подготовил 650 врачей, из них 185 составил выпуск 1942 года [6, л. 8].

После размещения вуза в Армавире была продолжена научно-исследовательская работа, при этом она приобрела ярко выраженный отпечаток военного времени. Сотрудниками Крымского медицинского института активно разрабатывались проблемы лечения различных видов ранений, ожогов, ран, борьбы с эпидемиями, решения экологических вопросов. В 1942 г. при институтезащищено четыре диссертации на степень кандидата медицинских наук. Закончены и представлены к защите шесть докторских диссертаций (профессора Н.В. Колпиков [4; 13, с. 92-93], Е.Л. Батинков [12, с. 66], М.Б. Матусов [13, с. $230 ; 15$, с. 100], К.П. Гесс-де-Кальве [12, с. 233], доценты О.Я. Мирецкий [13, с. 248; 15, с. 103], А.Д. Штейнберг [14, с. 328]). В первой половине 1942 г. совместно с Научным медицинским обществом были проведены две расширенные научно-оборонные конференции, на которых заслушано 85 докладов [6, л. 11].

С обустройством медицинского института в Армавире по мере возможности улучшались бытовые условия его сотрудников и студентов. Для последних имелась закрытая столовая, буфет и молочный киоск. С помощью местных организаций обустроена закрытая столовая для научных работников института и закрытый распределитель для профессоров, заведующих кафедрами и доцентов. Было 
налажено снабжение студентов и сотрудников института необходимыми промтоварами. Удалось организовать общежитие на 35 мест. При институте действовала сапожная и портняжная мастерские. Принимались меры к организации подсобного хозяйства [6, л. 15].

В конце июля 1942 г. линия фронта приблизилась к Армавиру. Остро стал вопрос об экстренной эвакуации Крыммединститута. Выезд вуза, осуществленный без фактического разрешения Правительства, в условиях военной суматохи, детально изложен в докладной записке С.Р. Татевосова в Наркомздав РСФСР от 20 октября 1942 года [6, л. 12 об.]. Из нее следует, что 20 июля 1942 г. C.P. Татевосовым был поднят вопрос перед Крымским правительством и краевыми организациями о необходимости подготовки института к эвакуации. Согласно указаниям директивных органов эвакуация была запрещена. 27 июля от СКВО получено уведомление о предоставлении институту двадцати вагонов, притом, что оборудование вуза с 20 июля хранилось в упакованном состоянии. С 30 июля C.Р. Татевосовым было разрешено самостоятельно покидать город студентам и работникам института. Потеряв надежду на организованную эвакуацию, коллектив вынужден был вместе с секретарем Партбюро т. Линецкой выйти из города ночью с первого на второе августа $[6$, л. 1$]$.

С.Р. Татевосов остался в Армавире, рассчитывая на возможность организации вывоза имущества вуза. В октябре 1942 г. он с горечью вспоминал события начала августа: «Мне удалось отправить только один вагон с имуществом и несколькими семьями сотрудников и группой студентов. <...> Беспрерывная бомбежка города $<. .>$ лишила нас надежды на получение транспорта. Получив контузию левой руки и осколочное ранение правой, я вынужден был выйти из города пешком в ночь со 2-го на 3-е августа. Единственный транспорт института - грузовая машина была отобрана комендантом города. Идя пешком, мы неоднократно подвергались бомбежке. $<\ldots>$ В дороге остался я один и шел пешком неделю, поддерживая свое существование гнилыми ягодами. <...> На ст. Георгиевской $<$...> военные подобрали меня, перевязали мне раны и привезли до станции Петропавловской возле Грозного. Отсюда мы пошли пешком до Грозного, а из Грозного ехали поездом до Орджоникидзе» $[6$, л. 2].

Коллективу вуза удалось собраться в Красноводске, откуда уполномоченный Наркомздрава тов. Александровский направил институт в Ашхабад. В Туркменской ССР вузу было отказано в размещении. Через пять дней после прибытия в Ашхабад была получена телеграмма о направлении института в Кзыл-Орду, куда сотрудники института прибыли 12 сентября 1942 года. Уже 20 сентября был начат новый набор, зачислено 170 человек. 1 октября были начаты учебные занятия [6, л. 2].

Крыммединституту на временное пользование частично было передано оборудование и библиотека эвакуированного в Алма-Ату Курского мединститута. Институт получил двухэтажное здание средней школы, разрешение использовать в учебных целях базу фельдшерской школы и иных лечебнопрофилактических учреждений города. По прибытии в Казахстан была начата организация подсобного хозяйства [6, л. 2 об.]. 24 февраля 1943 г. проведено заседание с членами правления колхоза Терек-Шай о предоставлении мединституту поливного участка 32 га, получен наряд на скот [7, л. 84-85].

Для научных работников и студентов были организованы столовые закрытого типа, однако качество питания (одноразовое из двух блюд) оставалось неудовлетворительным. Столовые работали с постоянными перебоями из-за недостатка продуктов, посуды. Заготовку топлива, в качестве которого вуз вынужден был использовать саксаул, институт осуществлял собственными силами, для чего была создана специальная бригада студентов во главе с преподавателями. Доставка осуществлялась с помощью четырех ослов, выделенных местными организациями [6, л. 4].

Из «Отчета директора Крымского медицинского института им. И.В. Сталина за февраль 1943 г.» установлено, что 3 февраля C.P. Татевосовым проведено совещание с хозяйственным аппаратом вуза по вопросам быта студентов с целью улучшения качества питания, контроля санитарного состояния учебного корпуса и общежития, налаживания охраны имущества. Принято решение о пла- 
нировании работы хозаппарата и повседневном контроле каждого работника помощником директора по хозяйственной части. На момент подготовки отчета проверка исполнения проводилась два раза и показала улучшение санитарного состояния в учебном корпусе, удовлетворительное санитарно-гигиеническое состояние общежитий, было доставлено несколько подвод топлива для учебного корпуса, организован буфет, составлена смета для закупки оборудования и ремонта столовой [7, л. 84-85].

Благодаря выявленным в фондах ГАРФ «Материалам по обследованию Крымского мединститута в г. Кзыл-Орда» частично восстановлены детали функционирования медицинского института в Казахстане. Документ содержит информацию о том, что профессорско-преподавательский состав и служащие института прибыли в Казахстан в полном составе. Эвакуировано также было 187 студентов, преимущественно старших курсов. Профессора и студенты были размещены в местной фельдшерско-акушерской школе. Для работы теоретических кафедр приспособлено помещение бывшей авиашколы. Здание двухэтажное, располагало 25 просторными аудиториями. Здесь же было обустроено студенческое общежитие на 150 человек. Местными органами здравоохранения из расформированных госпиталей было выделено необходимое количество кроватей, постельного белья. Клинические кафедры размещались на базе местной городской больницы, поликлиники, родильного дома и железнодорожной больницы. Часть студентов была трудоустроена в лечебных учреждениях города и на погрузочно-разгрузочных работах на железнодорожной станции [6, л. 3].

Осенью 1943 г. начальником Управления высшими медицинскими учебными заведениями Наркомздрава РСФСР К.Я. Шхвацабая была подготовлена краткая справка в отдел вузов ЦК ВКП(б) о положении Крыммединститута в первые годы войны, содержащая частичные сведения о профессорско-преподавательском составе вуза и его студенческом контингенте [7, л. 140-141]. Из документа следует, что до эвакуации из Симферополя на 1 января 1941 г. в составе института на 32 кафедрах работало: из числа заведующих ка- федрами докторов наук - 15 и 1 профессор кафедры, кандидатов наук - 9, 8 заведующих кафедрами без ученой степени. Кроме того, на кафедрах работало: доцентов - 8, из них 3 с ученой степенью кандидата наук, ассистентов, старших преподавателей и преподавателей -114 , из них -7 кандидатов наук. Во время оккупации Симферополя немецкими войсками повешен профессор психиатрии Н.И. Балабан [12, с. 59-60; 15, с. 12-13]. Мобилизовано в ряды Красной Армии: 3 профессора, 3 доцента, 15 ассистентов и 2 преподавателя. За время эвакуации мединститут лишился 8 профессоров заведующих кафедрами (на 1 февраля 1942 г.), которые трудились в госпиталях и других лечебных учреждениях. На 1 января 1943 г. в г. Кзыл-Орда в Крыммединституте были укомплектованы все кафедры (за исключением кафедр судебной медицины и организации здравоохранения) докторами наук. Вакантные ставки были заполнены преподавателями эвакуированного Сталинградского и Воронежского институтов. После возобновления работы этих институтов, часть профессоров вернулась на свои основные кафедры. До эвакуации из Симферополя по 1 февраля 1941 г. состояло всего студентов - 1350 . В первые дни войны студенты пятого курса были выпущены врачами. За время эвакуации: на 1 октября 1941 г. всего студентов 734, на 1 марта 1942 г. всего студентов - 474, на 1 июля 1943 г. всего студентов - 477. За военное время выпущено: 1941 г. $-190,1942$ г. $-177,1943$ г. - 107, всего 474 врача. На 1 октября 1943 г. вместе с новым набором контингент студентов составлял 773 человек, из них 250 обеспечены общежитием [7, л. 140-141].

К середине 1943 г. благодаря кропотливой работе администрации вуза во главе с C.P. Татевосовым, усилиям местных городских и республиканских органов власти условия пребывания в Кзыл-Орде эвакуированных сотрудников и студентов Крымского медицинского института приобрели рабочий характер, о чем свидетельствует ряд архивных документов. Из протокола первого заседания Библиотечного совета от 12 марта 1943 г. следует, что «библиотека института открыта с 10 ч утра до 7 ч вечера, в учебных комнатах до 11 ч вечера дежурит ежедневно с самыми не- 
обходимыми книгами работник библиотеки» [7, л. 25]. 19 марта 1943 г. состоялось первое заседание президиума Студенческого научного общества, были собраны материалы о работающих научных кружках, распределены функции между членами Правления [7, л. 25]. В отчете С.Р. Татевосова о работе директора Крыммединститута имени И.В. Сталина за март 1943 г. указано, что «на базе института организована студенческая столовая, к которой прикреплены и сотрудники, хотя кормят еще один раз в день и качество обедов недостаточное» [7, л. 22].

24 апреля 1943 г. на страницах газеты «Ленинский путь» (№ 84 (1495)) личную благодарность сотрудникам Крыммединститута выразил Секретарь ЦК ВКП(б), Председатель Совета народных комиссаров СССР, Председатель Государственного комитета обороны И.В. Сталин: «Прошу передать коллективу Крымского государственного медицинского института им. Сталина, собравшему 15000 руб. на строительство самолета, мой братский привет и благодарность Красной Армии. И. Сталин» [7, л. 15].

8 мая 1943 г. С.Р. Татевосов сообщал К.Я. Шхвацавая: «Крымский медицинский институт им. И.В. Сталина после трехкратной эвакуации обосновал свою работу с осени 1942 г. в г. Кзыл-Орда КазССР. Несмотря на исключительные трудности, Институт сумел за это время организовать хорошую клиническую базу, учебный корпус для теоретических кафедр, женское общежитие на 110 человек, столовую для студентов и сотрудников при учебном корпусе и подсобное хозяйство. В настоящее время институт организовал свою работу на основе стабильных учебных планов, готовит четвертый военный выпуск, проводит подготовительную работу по новому набору, оборудует лаборатории, аудитории и разворачивает библиотеку. В институте обучается 500 студентов» [7, л. 20]. С.Р. Татевосов также отметил, что ввиду стабилизации работы вуза в эвакуации «Институту необходимо увеличить контингент учащихся <...>, так как его материальные и учебные базы растут и гарантируют более высокий уровень учебной и научной работы к будущему году» [7, л. 20 об.].

Итог научной работы профессорско-преподавательского состава Крымского медин- ститута в эвакуации подвел «Отчет о выполнении плана научной работы Крымского медицинского института им. И.В. Сталина за 1943 год» [7, л. 155-161]. Из документа следует, что из семи запланированных докторских диссертаций одна отпала в связи со смертью автора, две защищены, две представлены к защите, две перенесены на 1944 год. Из одиннадцати кандидатских диссертаций семь защищено в 1943 г., две закончены и представлены к защите, одна по плану должна быть завершена в 1944 г., одна не закончена в связи с болезнью автора и включена в план 1944 года. Коллектив вуза работал над подготовкой научных монографий, справочных и учебных пособий, востребованных в военное время (профессор С.Р. Татевосов - учебное и справочное пособия по внутренним болезням, профессор В.Б. Шостакович [5; 13, c. 326] - руководство по психопатологии). Ряд разрабатываемых научных тем были направлены на практическое применение в местных условиях. Доцентом кафедры органической химии М.А. Поповым [13, с. 404; 15, с. 121] разработан метод получения фитина из отходов риса. Профессором кафедры гистологии Б.П. Хватовым $[1 ; 2 ; 14$, с. 241$]$ получен заменитель нафталина для хранения кожевенного сырья, предложена замена поваренной соли местной солью. В г. Кзыл-Орда за 1943 г. проведено пять научных конференций и пленумов организованного Медицинского общества, на которых было заслушано 38 научных докладов сотрудников Крыммединститута [7, л. $155-161]$.

Летом 1944 г., после успешного завершения Крымской наступательной операции Красной Армии, целью которой являлось освобождение Крымского полуострова, началась подготовка реэвакуации Крымского государственного медицинского института имени И.В. Сталина. 27 июля 1944 г. получен ответ Народного комиссара финансов А. Посконова № 08216 на запрос СНК РСФСР № 382-3 от 21 июля 1944 г. «Об отпуске Наркомздраву РСФСР дополнительно 672 тыс. руб. на расходы по реэвакуации Воронежского и Крымского мединститутов»: «Ходатайство Наркомздрава РСФСР об отпуске 485 тыс. руб. на выдачу подъемных работникам Воронежского и Крымского мединститутов по случаю 
реэвакуации может быть удовлетворено лишь по утверждении СНК СССР» [11, л. 1]. 5 августа 1944 г. издано распоряжение № 1857-р СНК РСФСР: «Разрешить Наркомздраву РСФСР израсходовать в 1944 г. в пределах сметы 100 тыс. руб. на реэвакуацию Воронежского и Крымского мединститутов» $[11$, л. 5].

В Симферополе директором Крыммединститута предпринимались меры для скорейшего возобновления работы вуза в Крыму. Требовалось не только вернуть в собственность института учебные корпуса, но и произвести в них хотя бы минимальный ремонт для возможности организации учебных занятий. Насущной задачей было наладить снабжение вуза как финансами, так и продовольствием, требовалось разместить возвращающихся студентов и профессорско-преподавательский состав, наладить их быт. Многие аспекты хозяйственно-бытовой жизни института приходилось возрождать практически заново.

Условия работы в течение осенне-зимнего семестра 1944/45 учебного года в недавно освобожденном, значительно пострадавшем за годы оккупации Симферополе были далеки от оптимальных, требовали значительных физических и моральных усилий. Учебный корпус института, расположенный по ул. Р. Люксембург, 27, не был возвращен вузу несмотря на многочисленные ходатайства администрации в различные инстанции и прошения Наркомздрава. Институт был вынужден довольствоваться одним корпусом. В нем были размещены общежитие на 400 человек, административная часть, библиотека, столовая. В комнатах общежития практически отсутствовала мебель, «мыла было недостаточно и выдавалось студентам по мере его получения. Организованного выхода в бани нет из-за отказа директора бани заключить договор с институтом. Кипятком студенты регулярно не обеспечены. Не было титана, был лишь самовар. <..> Здание общежития не отапливалось (не исправна отопительная система) $<\ldots>$. Остекление рам неполное. Электросветом общежитие не было обеспечено <...>. Изза серьезной порчи канализации внутренние уборные работали с перебоями и были дополнительно построены уборные во дворе» [8, л. 26]. При общежитии работали парикмахерская, сапожная, портняжная мастерские. При здании общежития было открыто шесть радиотрансляционных точек, организован клуб, обустроена витрина с центральными, местными и институтскими газетами.

В главном здании находились теоретические кафедры. При этом не хватало элементарного количества мебели в аудиториях, на практических занятиях и лекциях часть студентов вынуждена была заниматься стоя. Ощущался дефицит в лабораторном оборудовании, учебных пособиях [8, л. 24]. Несмотря на острую нехватку жилья в городе в первые послевоенные годы, профессорскопреподавательский состав, за исключением профессоров В.И. Рахмана и П.И. Ильинского, к 1945 г. был обеспечен квартирами. Для научного персонала вуза был открыт специальный магазин для отоваривания продуктовых карточек. Снабжение профессоров промышленными товарами осуществлялось с перебоями [8, л. 27].

В сентябре 1944 г. был организован отдел рабочего снабжения. При этом только за 1944 г. руководство ОРСа менялось два раза, руководитель и главный бухгалтер арестованы за хищение. Подсобное хозяйство было закреплено за институтом в октябре 1944 г. и «имело 600 га земли < ...>, 34 головы крупного рогатого скота, 150 голов мелкого скота, 6 лошадей, повозки, один трактор (в ремонте)» [8, л. 24]. При институте оборудована кухня, организована студенческая столовая и магазин. Питание студентов было одноразовым, не хватало посуды.

После реэвакуации институт не имел собственного транспорта, но к началу 1945 г. за вузом уже числилось: «одна повозка, три лошади, легковая машина Мерседес, грузовая $(1,5$ т) ГАЗ, грузовая (2 т) американская. Две машины на ходу, но работают с большими перебоями из-за отсутствия бензина, покрышек, камер. Институт пользуется главным образом транспортом воинских частей (шефы)» $[8$, л. 26].

«Справка о состоянии по основным показателям работы Крымского медицинского института им. И.В. Сталина на апрель 1945 г.» от 14 апреля 1945 г. подводит промежуточный итог первоначального этапа восстановления вуза после его возвращения в Симферополь. Из нее следует, что в институте после 
реэвакуации числилось всего 250 студентов. К началу 1944/45 учебного года их количество было уже более 1000 человек. На 1 апреля 1945 г. за кафедрой патологической зоологии был закреплен один аспирант и пять клинических ординаторов. К этому времени в институте трудилось 22 профессора, из них 20 докторов наук [8, л. 22].

В 1944 г. научным коллективом института выполнено по плану 26 научных работ, из которых защищено две докторские и три кандидатские диссертации. Подготовлен к печати «Сборник научных работ института за годы Отечественной войны». В 1944 г. было проведено шесть научных общеинститутских конференций, на которых заслушано 65 научных докладов по различным вопросам медицины. Продолжало работу организованное в 1943 г. Студенческое научное общество. Исходя из докладной записки С.Р. Татевосова Народному комиссару здравоохранения РСФСР А. Третьякову, «за годы войны в Крыммединституте <...> получило ученую степень доктора наук 6 человек, кандидата наук 18 человек, закончено свыше 150 научных работ» [8, л. 47-47 об.].

Результаты. Изучение и введение в научный оборот нового комплекса документов, отложившихся в Государственном архиве Российской Федерации, позволило впервые детально восстановить историю Крымского государственного медицинского института имени И.В. Сталина в годы Великой Отечественной войны. Воссоздан страшный маршрут эвакуационных мытарств коллектива института (Симферополь - Армавир - Тбилиси - Красноводск - Джамбул - вновь Армавир - Орджоникидзе - Баку - Красноводск - КзылОрда - Симферополь). Основными направлениями работы вуза, кроме профильной образовательной деятельности, являлись: оказание всесторонней помощи медицинским учрежде- ниям города (работа студентов и преподавателей в клиниках и госпиталях, консультирование местных специалистов, обладавших зачастую более низкой квалификацией, контроль за санитарной обстановкой и т. д.), подготовка медицинских работников для нужд фронта, острая нехватка которых в рядах Красной Армии ощущалась с первых дней войны. В итоге с июня 1941 по июль 1944 г. было выпущено 850 врачей.

Благодаря героической, во многом самоотверженной работе сотрудников Крымского государственного медицинского института имени И.В. Сталина (Е.Л. Батинков, К.П. Гессде-Кальве, Н.В. Колпиков, М.Б. Матусов, О.Я. Мирецкий, А.Д. Штейнберг и др.) и, прежде всего, его директора С.Р. Татевосова в годы Великой Отечественной войны, большую часть которой пришлось провести в вынужденной эвакуации, удалось не только сохранить вуз, но и в кратчайшие сроки наладить его работу в г. Кзыл-Орда Казахской ССР, преодолевая многочисленные трудности (нехватка помещений, учебных пособий, плохо организованный быт студентов и сотрудников вуза и т. д.), сопровождающие военное время. После возвращения института в Симферополь в августе 1944 г. сразу же была организована работа по его полноценному восстановлению, что позволило вузу в дальнейшем не только не утратить лидирующие позиции в регионе, но и стать одним из ведущих медицинских научно-образовательных центров в стране.

\section{ПРИМЕЧАНИЯ}

${ }^{1}$ Цит. по: [2, л. 2].

${ }^{2}$ В настоящий момент - Медицинская академия имени С.И. Георгиевского (структурное подразделение) ФГАОУ ВО «Крымский федеральный университет имени В.И. Вернадского». 


\section{ПРИЛОЖЕНИЕ}

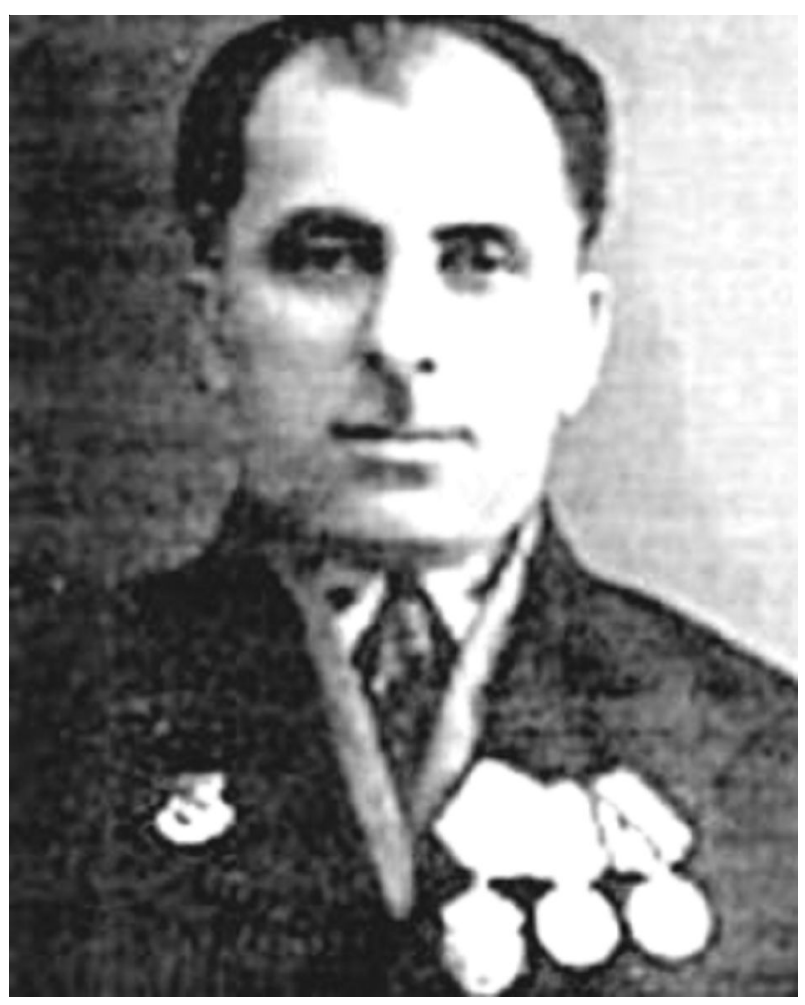

Рис. 1. Директор Крымского медицинского института во время Великой Отечественной войны (1941-1945 гг.), профессор Сергей Романович Татевосов (Музей истории КФУ им. В.И. Вернадского, фонды)

Fig. 1. Director of Crimean Medical Institute during the Great Patriotic War, Professor Sergey R. Tatevosov (Museum of History of V.I. Vernadsky Crimean Federal University, funds)

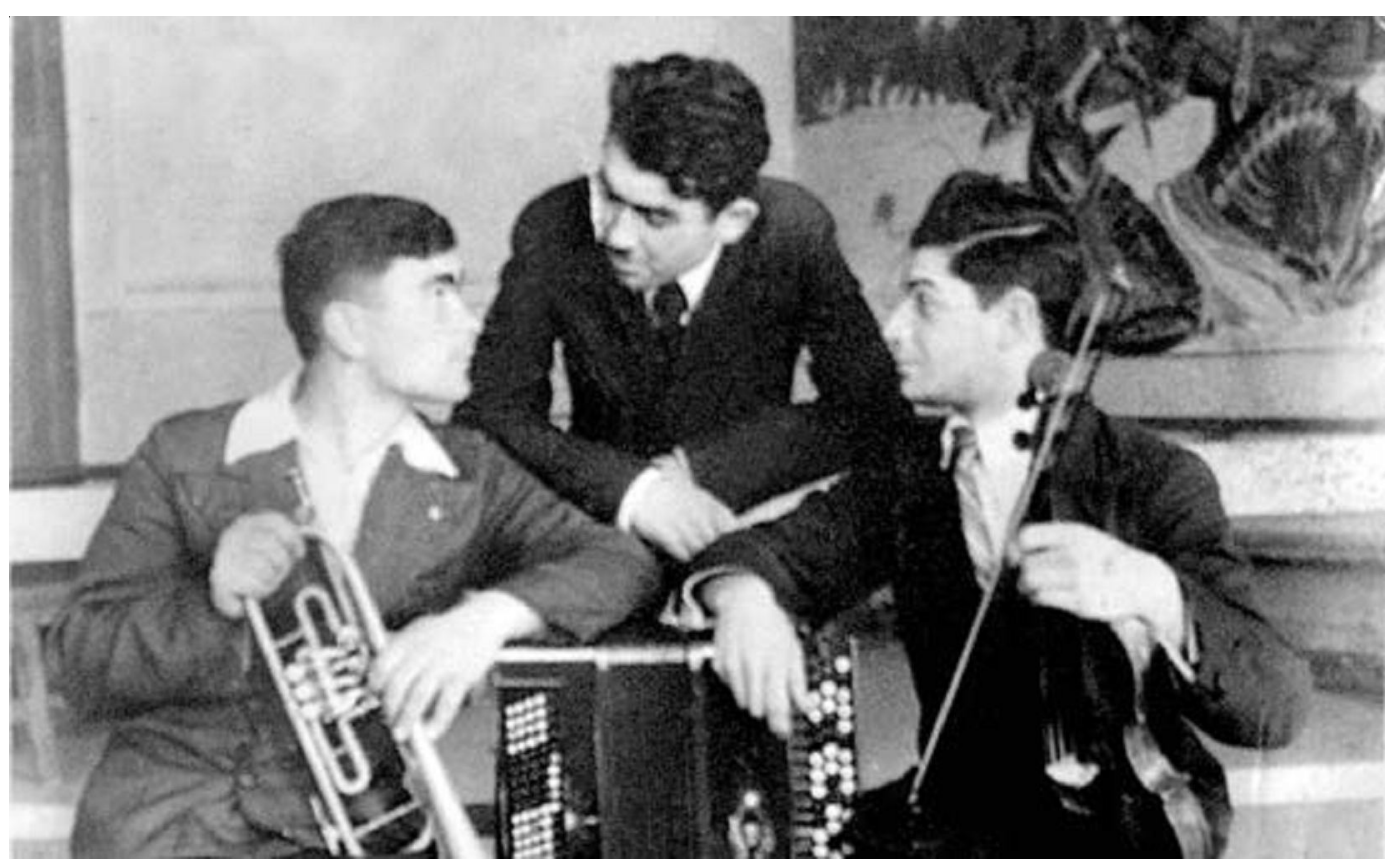

Рис. 2. Студенты Крымского медицинского института перед уходом на фронт, июнь 1943 года. Слева направо: Л. Ларичев, А. Иосис, С. Аоахис (Музей истории КФУ им. В.И. Вернадского, фонды)

Fig. 2. Students of Crimean Medical Institute before leaving for the front, June 1943. From left to right: L. Larichev, A. Iosis, S. Aoakhis (Museum of History of V.I. Vernadsky Crimean Federal University, funds) 


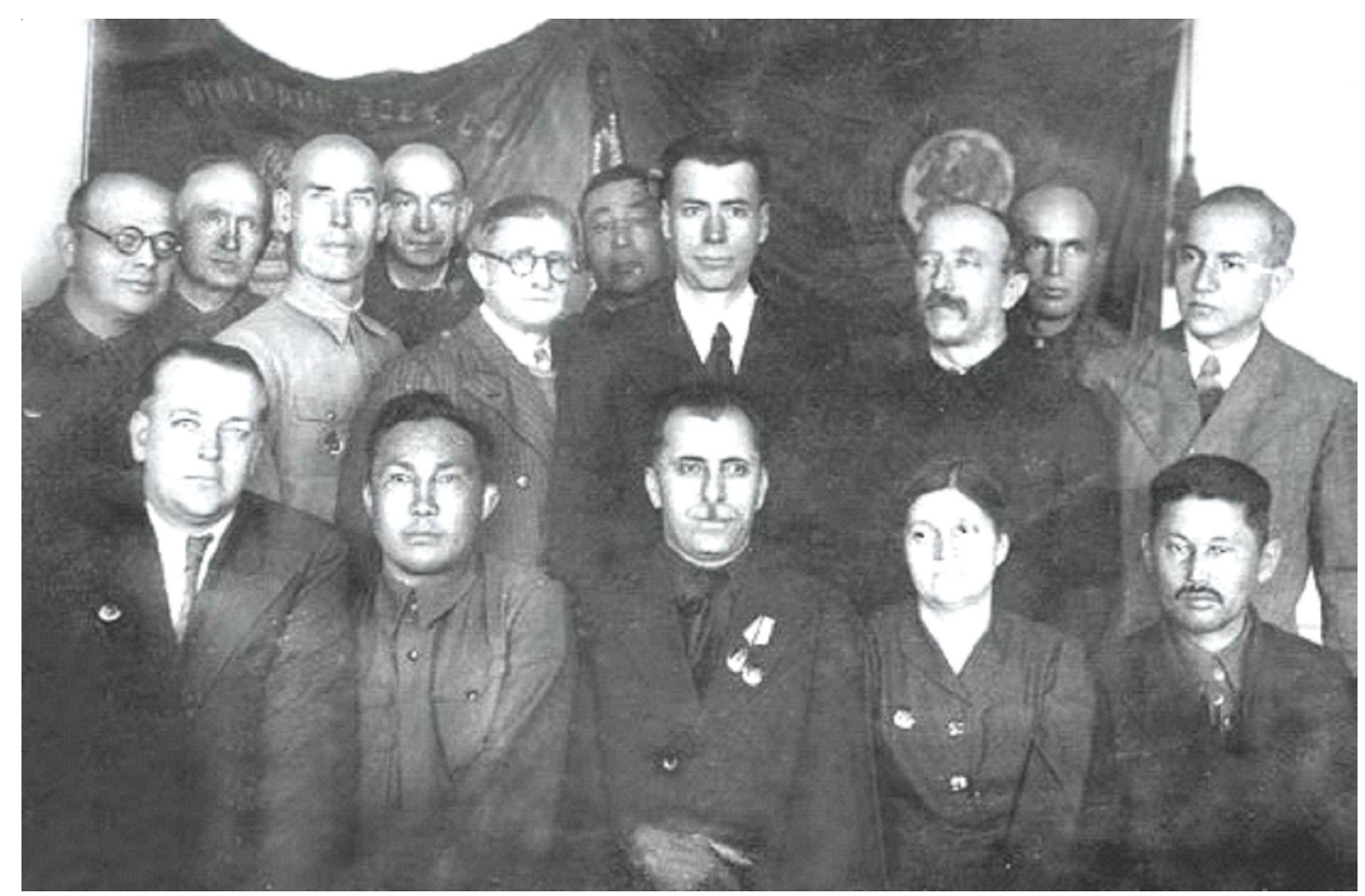

Рис. 3. Директор Крымского мединститута С.Р. Татевосов с преподавателями. г. Кзыл-Орда, 1943 г. (Музей истории КФУ им. В.И. Вернадского, фонды)

Fig. 3. Director of Crimean Medical Institute S.R. Tatevosov with lecturers. Kzyl-Orda, 1943 (Museum of History of V.I. Vernadsky Crimean Federal University, funds)

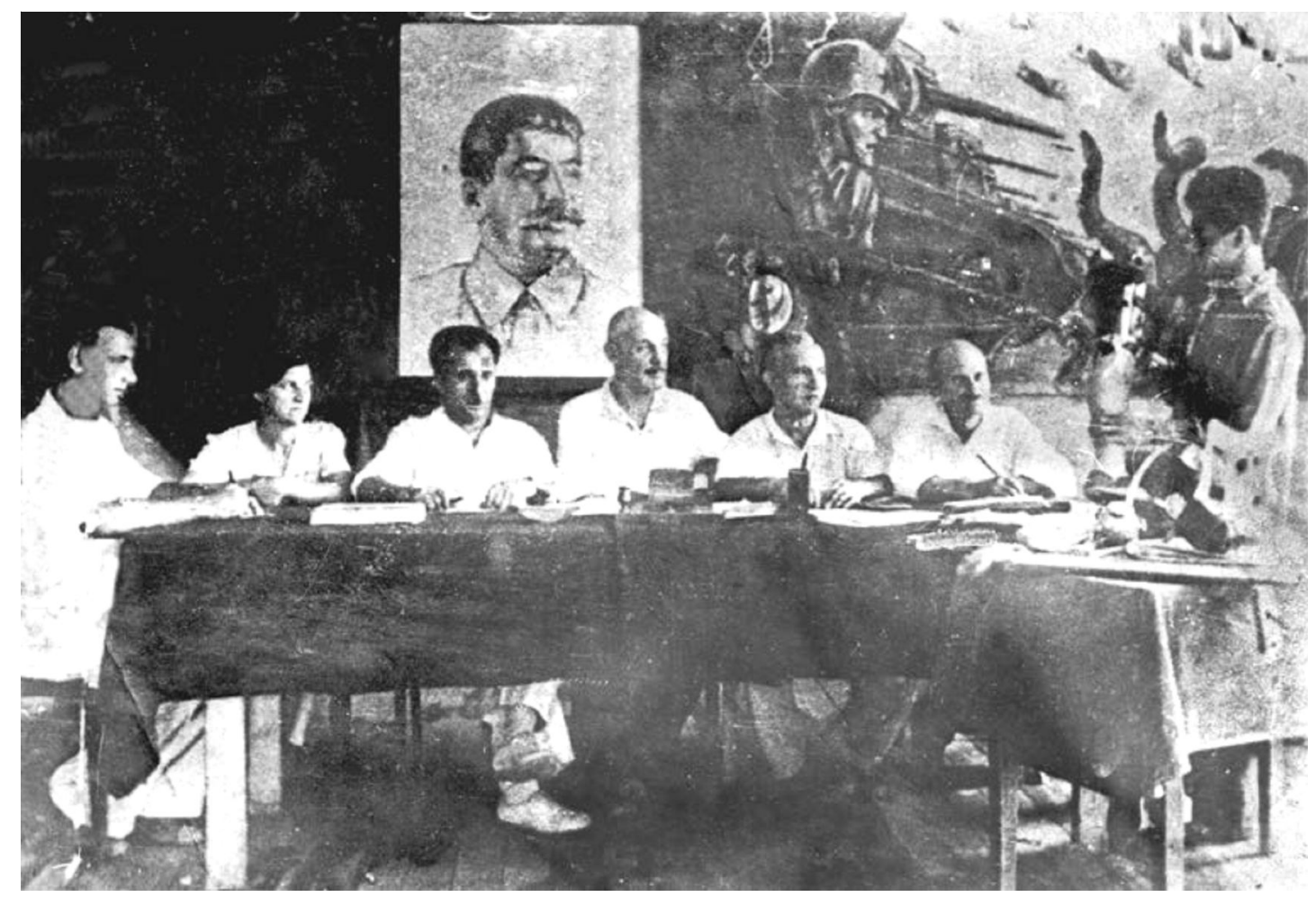

Рис. 4. Работает Государственная экзаменационная комиссия. г. Кзыл-Орда, 1943 г. (Музей истории КФУ им. В.И. Вернадского, фонды)

Fig. 4. The State Examination Commission is Working. Kzyl-Orda, 1943 (Museum of History of V.I. Vernadsky Crimean Federal University, funds) 
А.А. Непомнящчий, Д.А. Ломакин. «Преодолевая нечеловеческие трудности»

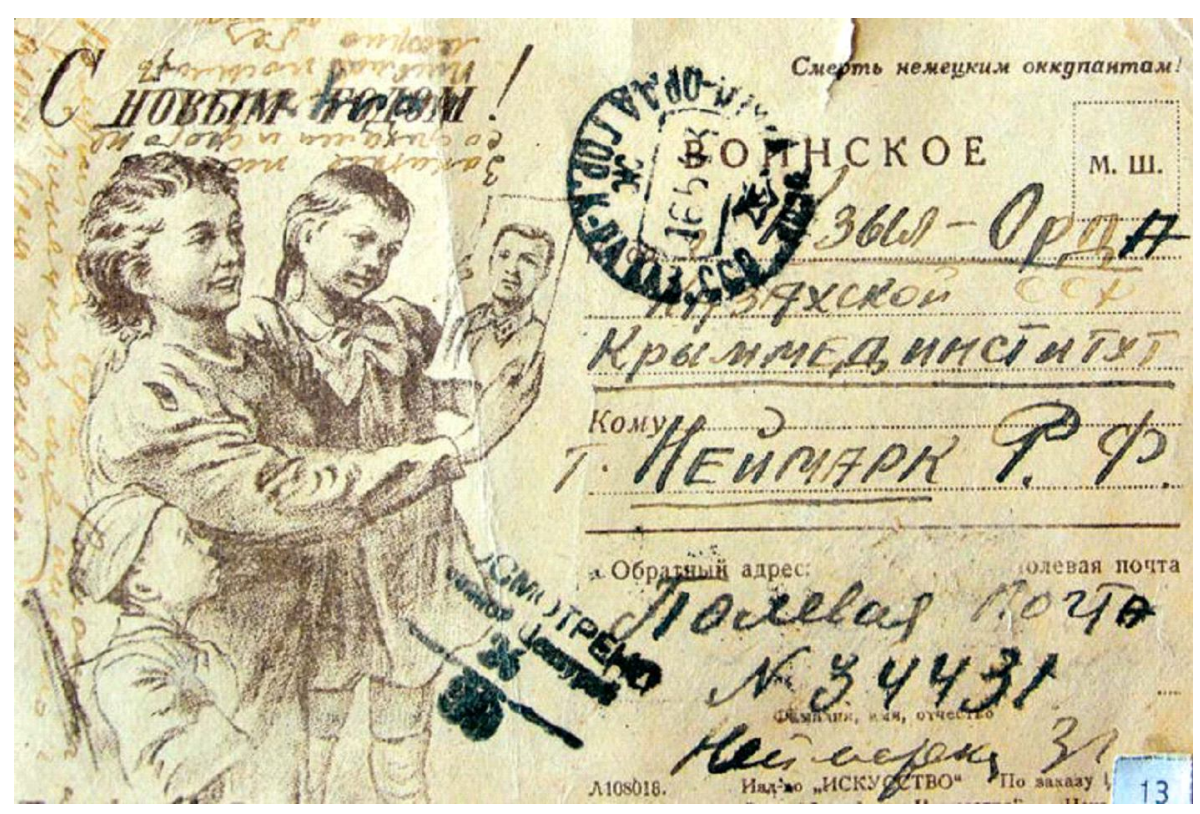

Рис. 5. Письмо майора медслужбы, до войны сотрудника Крымского мединститута З.Г. Неймарка, с фронта в Кзыл-Орду своей супруге - лаборанту института Ф.Ф. Неймарк

(Музей истории КФУ им. В.И. Вернадского, фонды)

Fig. 5. Letter of major of medical service, before the war employee of Crimean Medical Institute Z.G. Neymark from the front to Kyzyl-Orda to his wife - laboratory assistant of the institute

(Museum of History of V.I. Vernadsky Crimean Federal University, funds) 


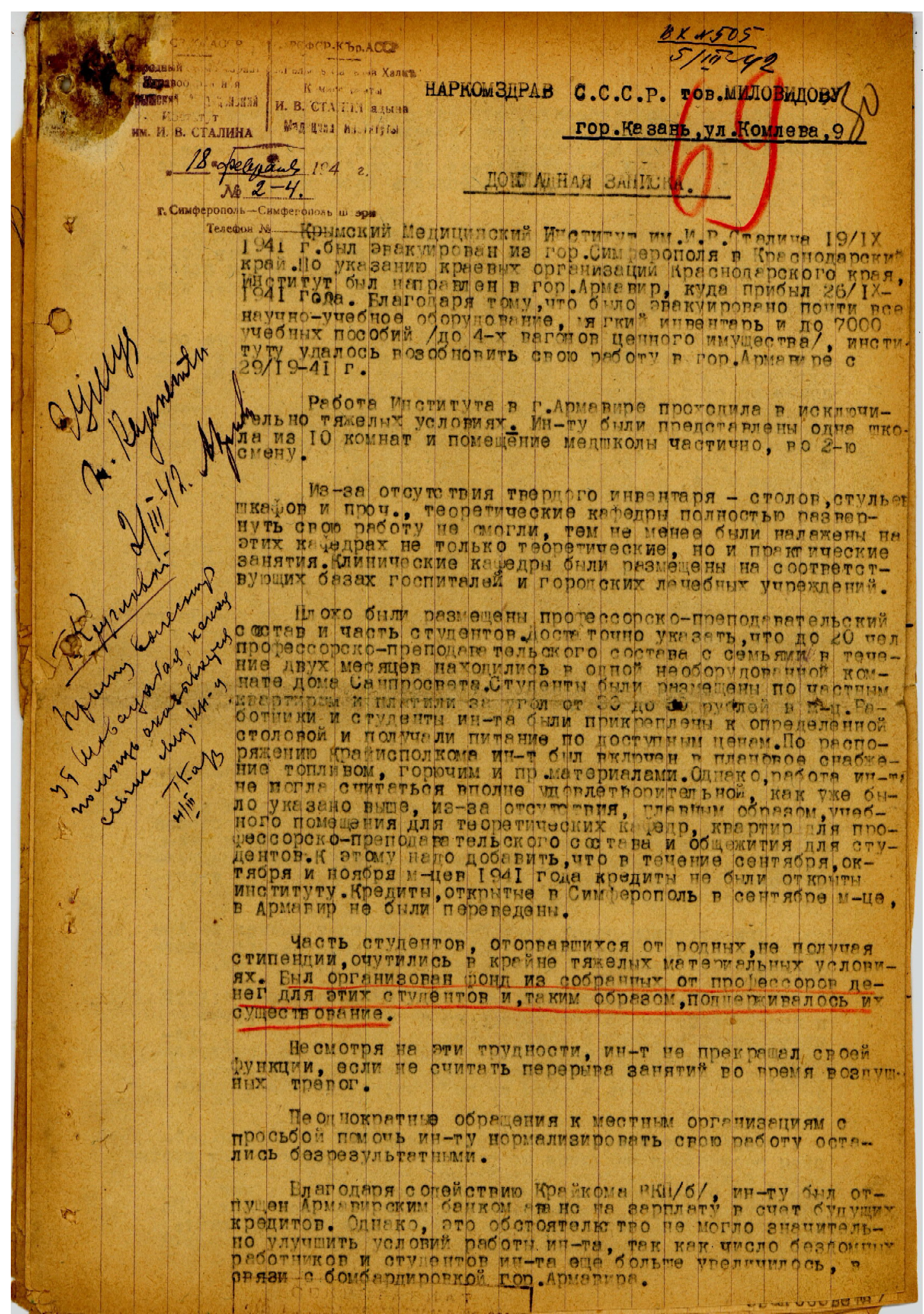

Рис. 6. Первый лист докладной записки С.Р. Татевосова в Народный комиссариат здравоохранения СССР заместителю Народного комиссара здравоохранения СССР С.И. Миловидову о положении дел в Крыммединституте. 18 февраля 1942 г. (ГАРФ, ф. 482, оп. 47, д. 849, л. 30)

Fig. 6. The first sheet of S.R. Tatevosov's memorandum report to the People's Commissariat of Health of the USSR to Deputy People's commissar of health of the USSR S.I. Milovidov concerning the situation in Crimean Medical Institute. February 18, 1942 (State Archive of the Russian Federation, f. 482, op. 47, d. 849, 1. 30) 


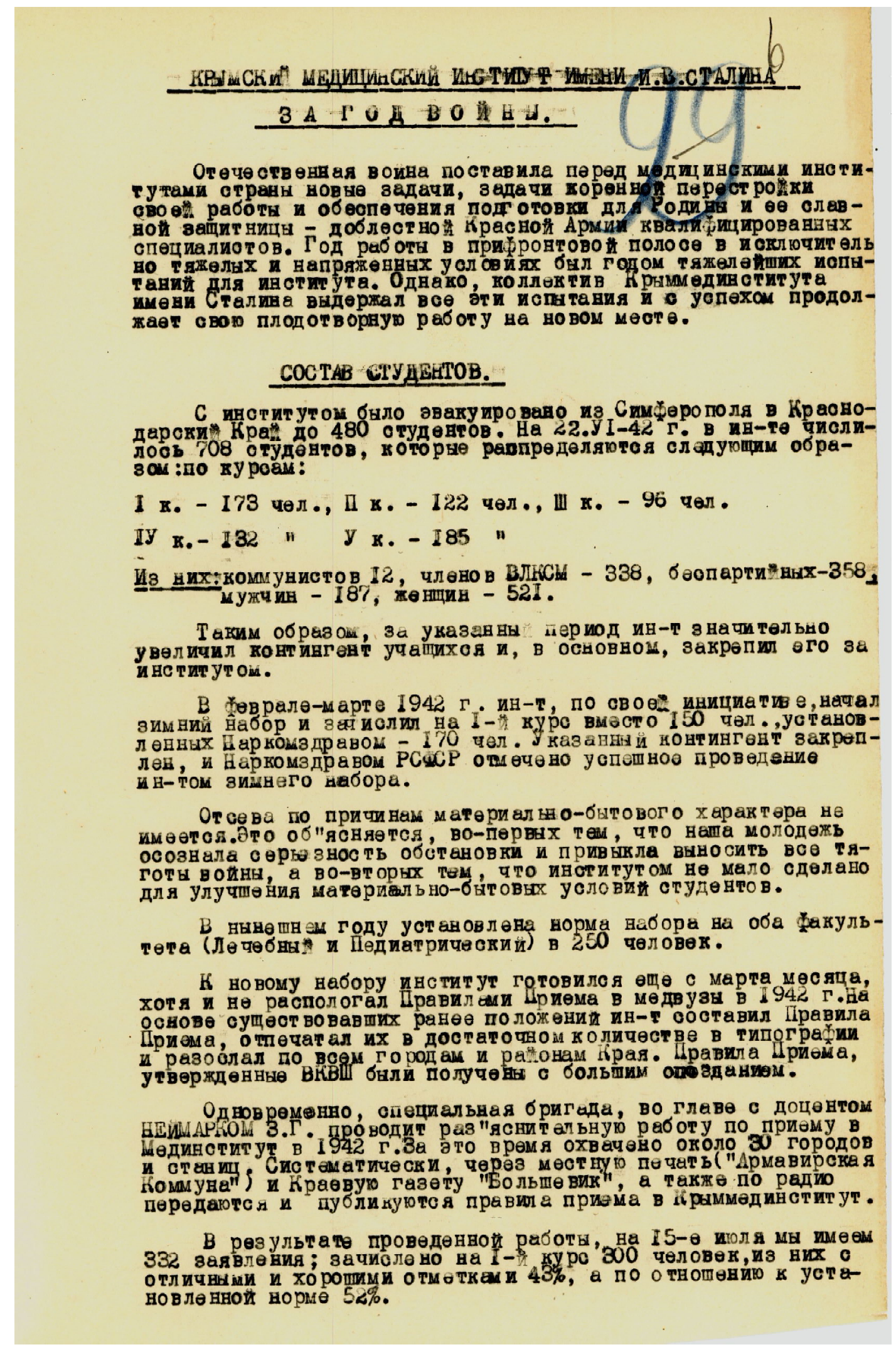

Рис. 7. Первый лист докладной записки С.Р. Татевосова «Крымский медицинский институт имени И.В. Сталина за год войны». 15 июля 1942 г. (ГАРФ, ф. 482, оп. 47, д. 849, л. 6)

Fig. 7. The first sheet of S.R. Tatevosov's memorandum report "I.V. Stalin Crimean State Medical Institute during the year of the war". July 15, 1942 (State Archive of the Russian Federation, f. 482, op. 47, d. 849, 1. 6) 


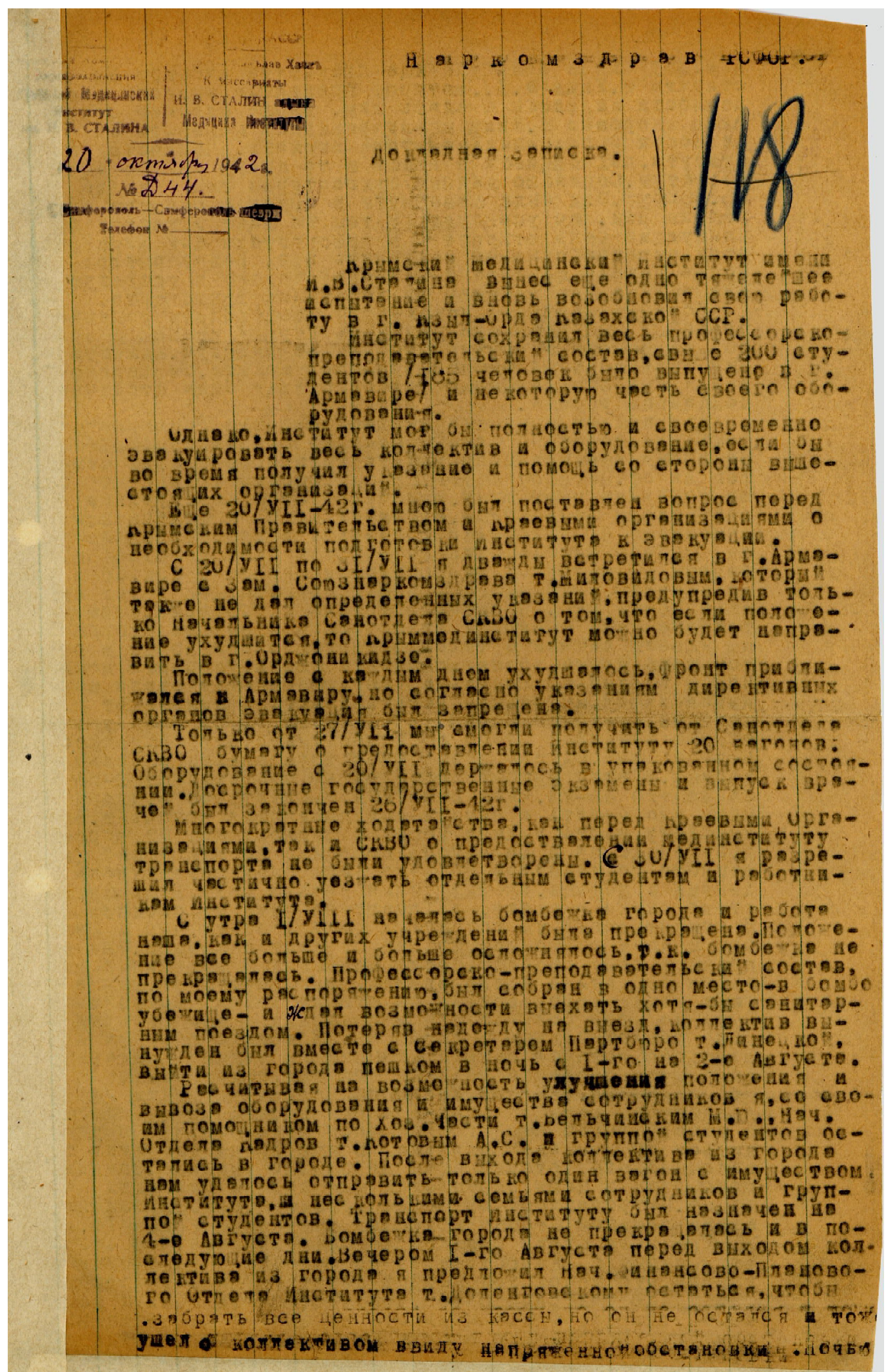

Рис. 8. Первый лист докладной записки С.Р. Татевосова в Наркомздав РСФСР от 20 октября 1942 г. о положении вуза в первые месяцы войны (ГАРФ, ф. 482, оп. 47, д. 849, л. 1)

Fig. 8. The first sheet of S.R. Tatevosov's memorandum report to People's Commissariat of Health of the RSFSR of October 20, 1942 concerning the Situation of the University in the first months of the war

(State Archive of the Russian Federation, f. 482, op. 47, d. 849, n. 1) 


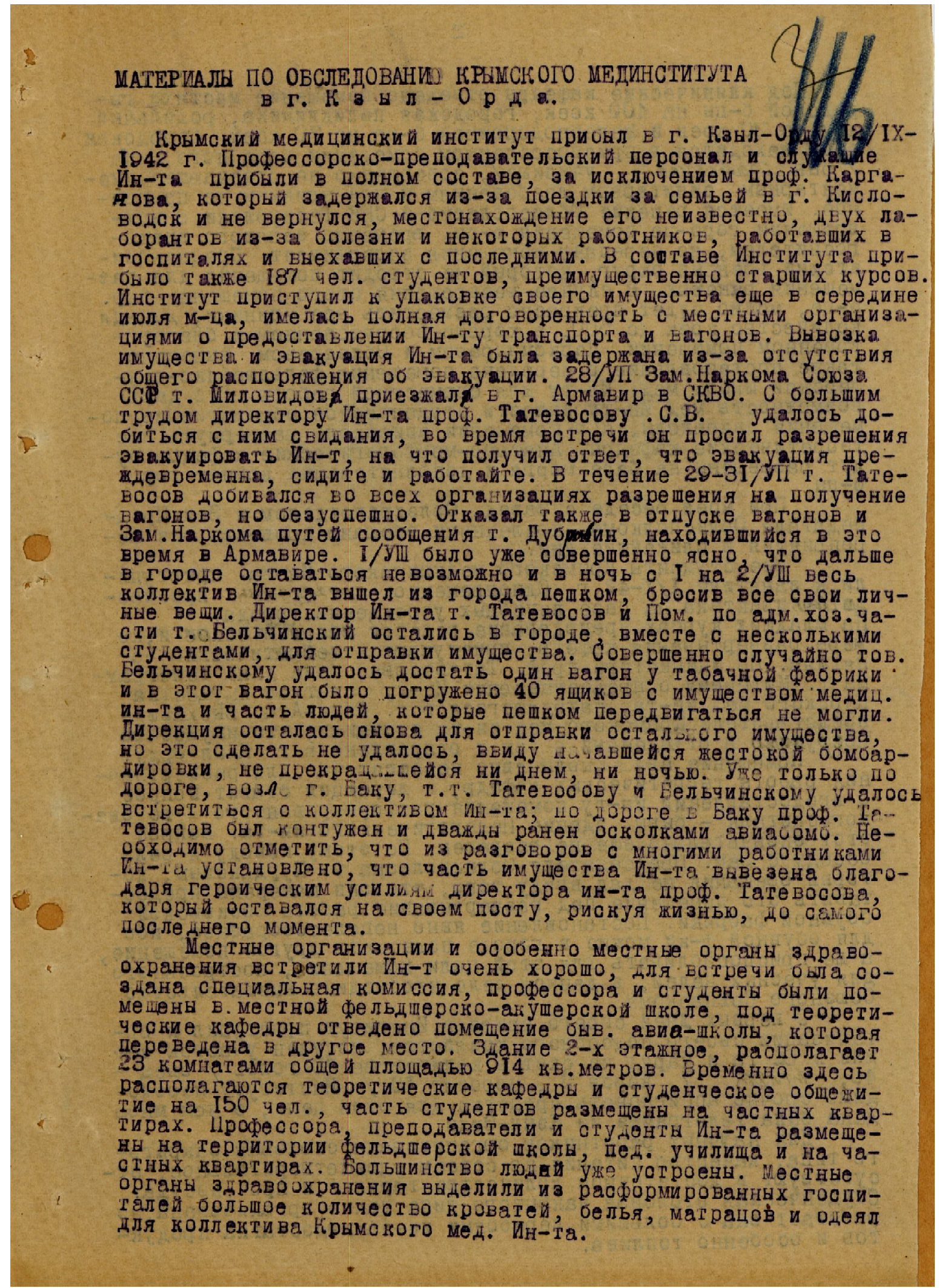

Рис. 9. Первый лист «Материалов по обследованию Крымского мединститута в г. Кзыл-Орда»

Народным комиссариатом здравоохранения. Без даты (ГАРФ, ф. 482, оп. 47, д. 849, л. 3)

Fig. 9. The first sheet of "Materials on the inspection of Crimean Medical Institute in Kzyl-Orda" by the People's Commissariat of Health. Undated (State Archive of the Russian Federation, f. 482, op. 47, d. 849, 1. 3 ) 


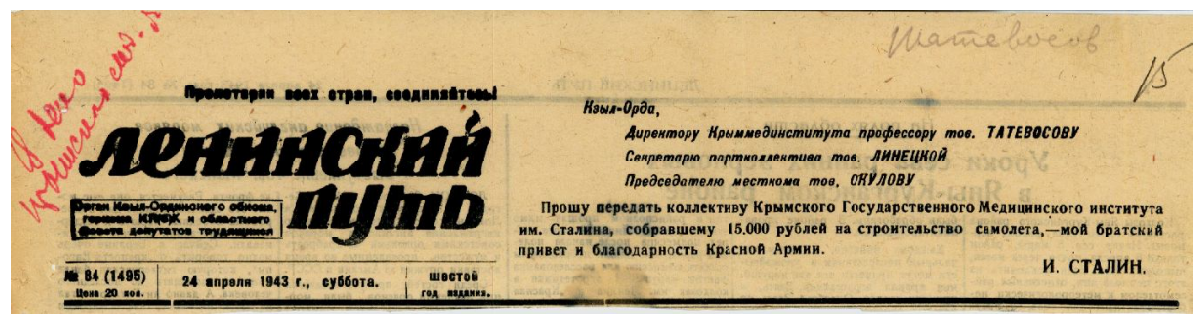

Рис. 10. Фрагмент страницы газеты «Ленинский путь», № 84 (1495), с личной благодарностью сотрудникам Крыммединституга И.В. Сталина. 24 апреля 1943 г. (ГАРФ, ф. 482, оп. 47, д. 1671, л. 15)

Fig. 10. Fragment of the page of "Leninskiy put" newspaper, no. 84(1495) with a personal gratitude to the staff of I.V. Stalin Crimean Medical Institute. April 24, 1943 (State Archive of the Russian Federation, f. 482, op. 47, d. 1671, 1. 15)

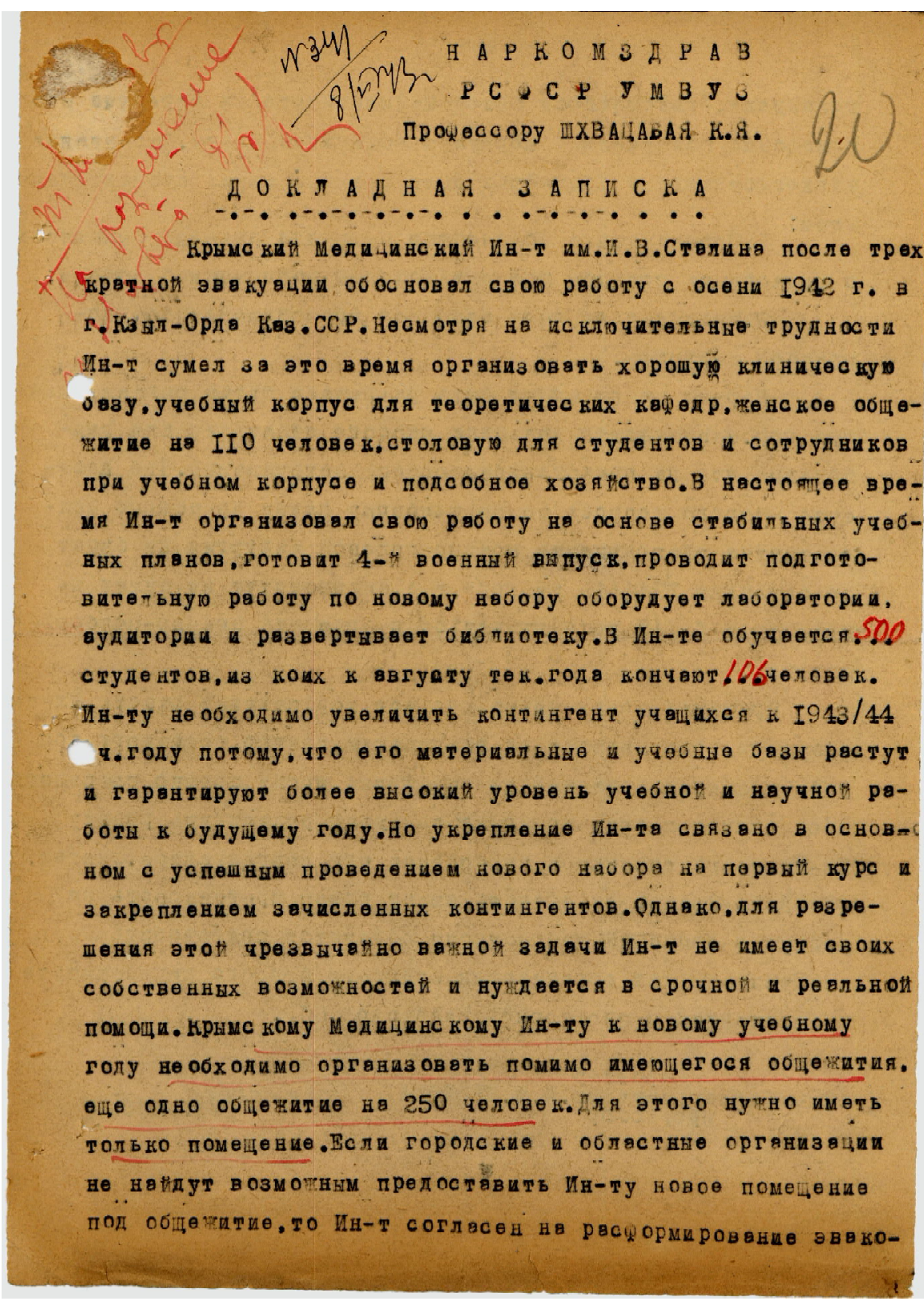

Рис. 11. Первый лист докладной записки С.Р. Татевосова начальнику Управления высшими медицинскими учебными заведениями Наркомздрава РСФСР К.Я. Шхвацабая. 8 мая 1943 г. (ГАРФ, ф. 482, оп. 47, д. 1671, л. 20)

Fig. 11. The first sheet of S.R. Tatevosov's memorandum report to head of the Department of Higher Medical Educational Institutions of the People's Commissariat of Health of the RSFSR K. Ya. Shkhvatsabay. May 8, 1943

(State Archive of the Russian Federation, f. 482, op. 47, d. 1671, 1. 20) 


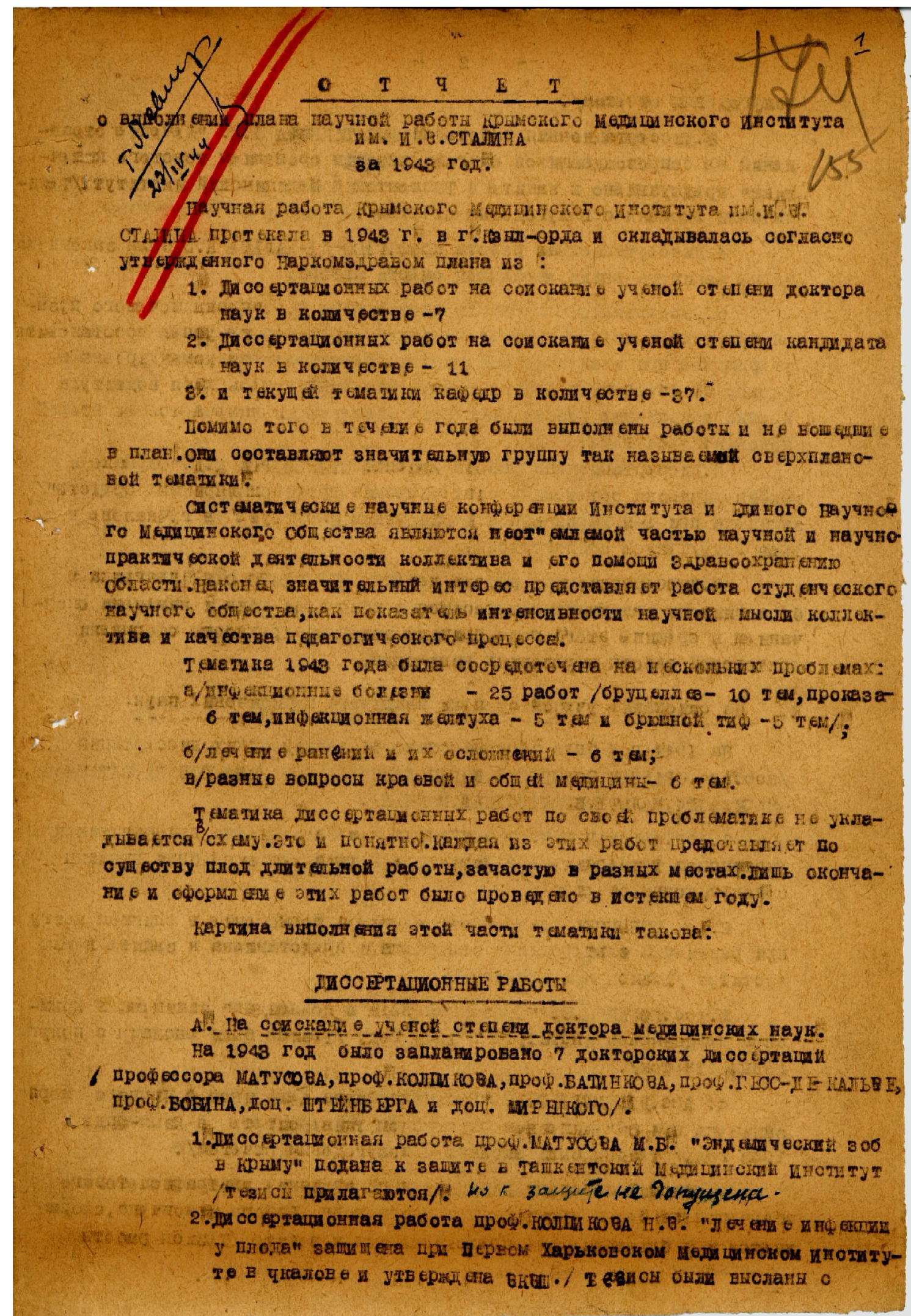

Рис. 12. Первый лист Отчета о выполнении плана научной работы Крымского медицинского института им. И.В. Сталина за 1943 г. (ГАРФ, ф. 482, оп. 47, д. 1671, л. 155)

Fig. 12. The first sheet of the report on the implementation of the plan of scientific work of I.V. Stalin Crimean Medical Institute for 1943 (State Archive of the Russian Federation, f. 482, op. 47, d. 1671, 1. 155) 


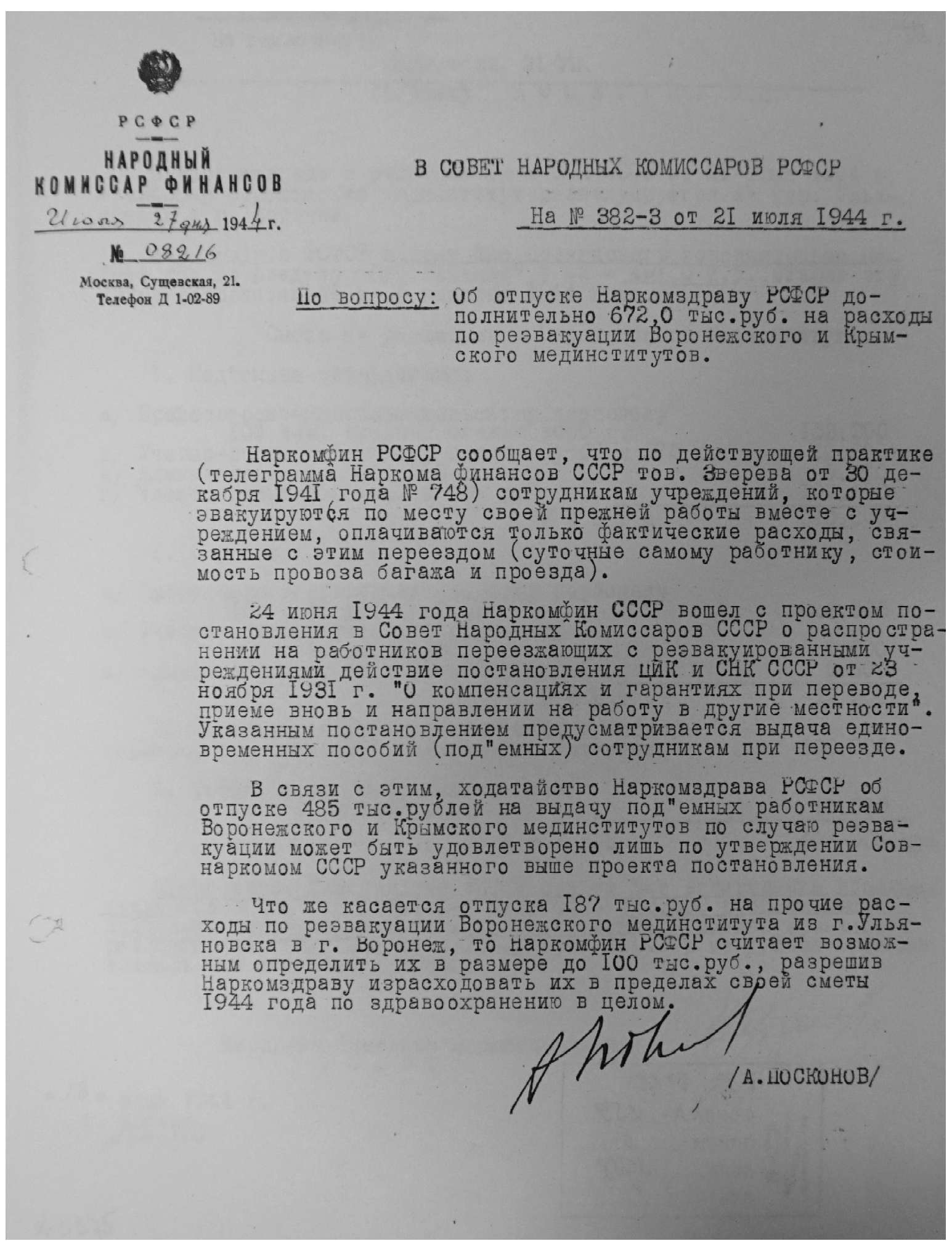

Рис. 13. Ответ Народного комиссара финансов А. Посконова № 08216 на запрос СНК РСФСР № 382-3 от 21 июля 1944 г. «Об отпуске Наркомздраву РСФСР дополнительно 672 тыс. руб. на расходы по реэвакуации Воронежского и Крымского мединститутов».

27 июля 1944 г. (ГАРФ, ф. А-259, оп. 5, д. 3088, л. 1)

Fig. 13. Response of the People's commissar of finance A. Poskonov no. 08216 to the request of the Council of People's Commissars of the RSFSR no. 382-3 Dated July 21, 1944 "On allocating to the People's Commissariat of Health of the RSFSR additional 672 thousand rubles for the costs of re-evacuation of Voronezh and Crimean

Medical Institutes". July 27, 1944 (State Archive of the Russian Federation, f. A-259, op. 5, d. 3088, 1. 1) 


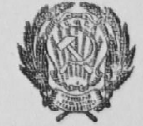 \\ T. Topucabcusary \\ СОВЕТ НАРОДНЫХ КОМИССАРОВ РСФСР
}

\author{
PACIOPTIEEUVE IR 1857-p \\ or 5 aвгуста 1944 roma \\ Г. МосквQ.
}

Разрешить Наркомздраву РС исР израсходовать в 1944 Году в пределак сметн 100 тыс.рублей ва реәвакуацию Воровежского 4 Крниского меднаститутов.

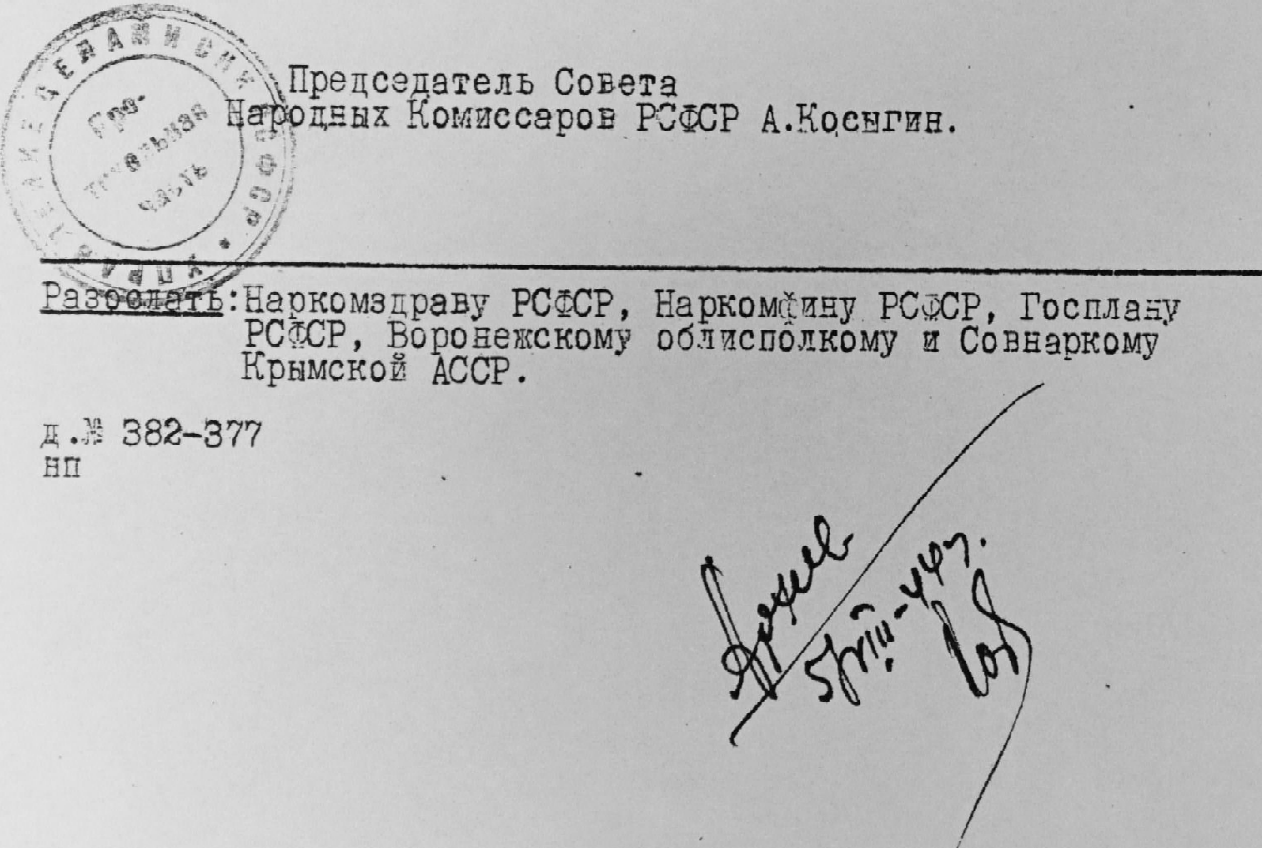

Рис. 14. Распоряжение № 1857-р СНК РСФСР о расходовании средств на реэвакуацию Воронежского и Крымского мединститутов. 5 августа 1944 г. (ГАРФ, ф. А-259, оп. 5, д. 3088, л. 5)

Fig. 14. Order no. 1857-p of the Council of People's Commissars of the RSFSR on spending funds for the re-evacuation of Voronezh and Crimean Medical Institutes. August 5, 1944 (State Archive of the Russian Federation, f. A-259, op. 5, d. 3088, 1. 5) 


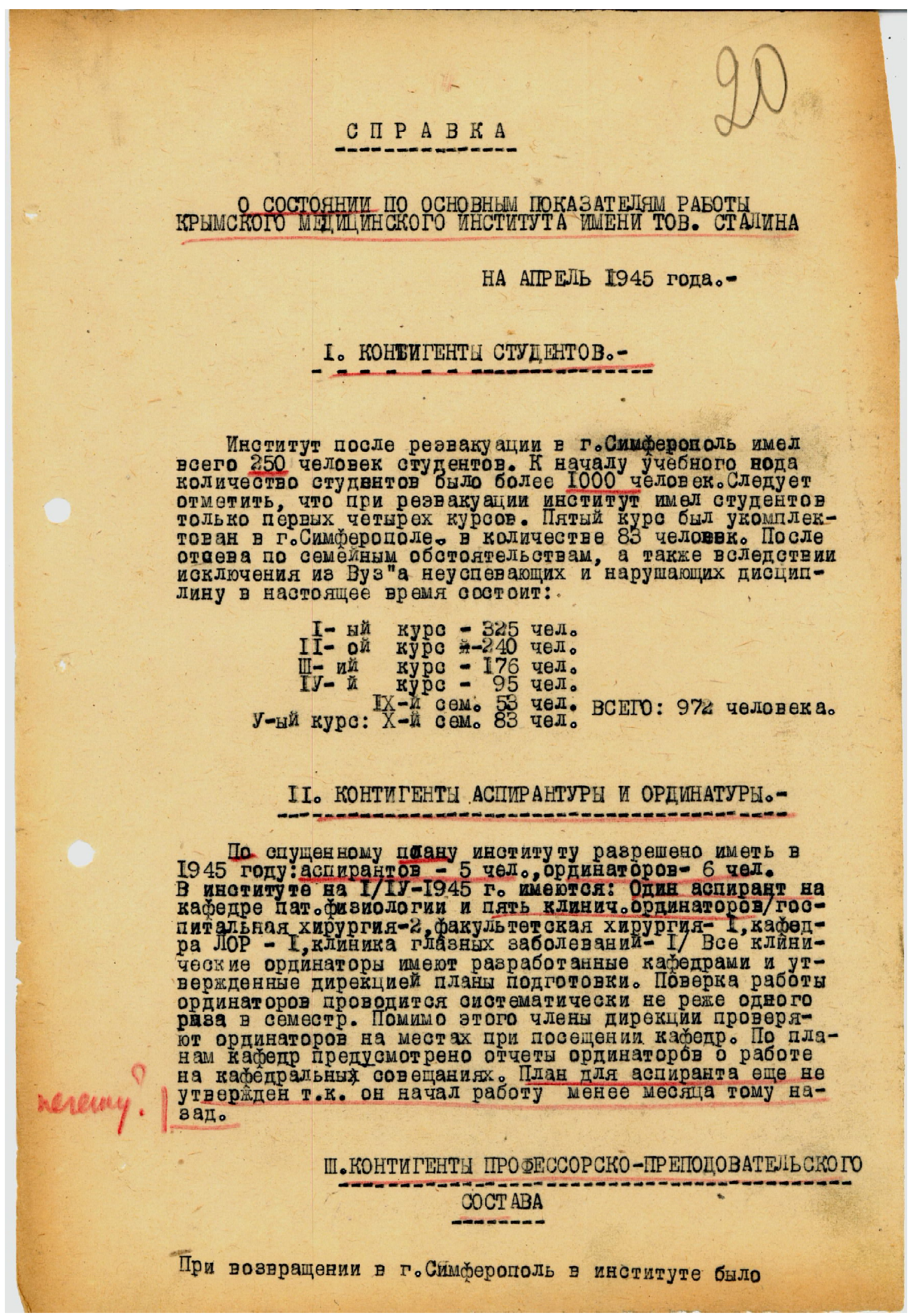

Рис. 15. Справка о состоянии по основным показателям работы Крымского медицинского института им. И.В. Сталина на апрель 1945 года. 14 апреля 1945 г. (ГАРФ, ф. 482, оп. 47, д. 3899, л. 20)

Fig. 15. Information about the state of the main indicators of I.V. Stalin Crimean Medical Institute in April 1945. April 14, 1945 (State Archive of the Russian Federation, f. 482, op. 47, d. 3899, 1. 20) 


\section{СПИСОК ЛИТЕРАТУРЫ}

1. Бабанин, А. А. Профессор Б. П. Хватов один из основоположников Крымской морфологической школы / А. А. Бабанин // Таврический медико-биологический вестник. - 2002. № 3. - С. 8-9.

2. Бобин, В. В. Воспоминания о профессоре Борисе Павловиче Хватове / В. В. Бобин // Таврический медико-биологический вестник. - 2002. Т. 5, № 3. - С. 14-15.

3. 85 лет Медицинской академии имени С.И. Георгиевского Федерального государственного образовательного учреждения «Крымский федеральный университет имени В.И. Вернадского» / авт.-сост.: Н. В. Иванова, Н. Н. Каладзе, Ю. Ю. Сугробова [и др.]. - Симферополь : Н. Орианда, 2016. - 180 c.

4. Кривчик, А. А. Научная деятельность основателя кафедры патологической физиологии медфака БГУ профессора Н. И. Колпикова: к 80-летию со дня рождения / А. А. Кривчик, Е. И. Шишко // Отчетная научная конференция Минского мединститута, июнь 1969 г. : тез. докл. Минск : Изд-во Минского мединститута, 1969. - С. 132-133.

5. Лисица, Г. И. В.В. Шостакович и украинская психиатрия / Г. И. Лисица, Л. З. Захарченко // История украинской психиатрии : сб. науч. работ Украинского научно-исследовательского института клинической и экспериментальной неврологии и психиатрии и Харьковской городской клинической психиатрической больницы № 15 (Сабуровой дачи) / под ред. И. И. Кутько, П. Т. Петрюка. - Харьков : [б. и.], 1994. - Т. 1.-С. 102-103.

6. Материалы о деятельности Крымского медицинского института за 1942 г. (отчеты, справки, сведения и др.) // Государственный архив Российской Федерации (ГАРФ). - Ф. А-482. - Оп. 47. Д. $849 .-39$ л.

7. Материалы о деятельности Крымского медицинского института за 1943 г. (отчеты института об учебной, лечебной, научной работе, о ходе экзаменационных сессий, протоколы заседаний Ученого совета, переписка института с Наркомздравом РСФСР и т. д.) // Государственный архив Российской Федерации (ГАРФ). - Ф. А-482. - Оп. 47. Д. 1671. -95 л.

8. Материалы о деятельности Крымского мединститута за 1945 г. (отчеты, планы, сведения и др.) // Государственный архив Российской Федерации (ГАРФ). - Ф. А-482. - Оп. 47. - Д. 3899. - 156 л.

9. Непомнящий, А. А. История Крымского федерального университета имени В. И. Вернадского в документах и фотографиях / А. А. Непомнящий, А. С. Кравчук. - Белгород : Константа, 2018. -352 c.
10. Непомнящий, А. А. «Работали несмотря ни на что»: Крымский государственный педагогический институт имени М. В. Фрунзе в годы Великой Отечественной войны : по материалам фондов Государственного архива Российской Федерации / А. А. Непомнящий, Д. А. Ломакин, Е. В. Бебешко // Ученые записки Крымского федерального университета им. В.И. Вернадского. Исторические науки. - 2018. - Т. 4 (70), № 3. - С. 84-105.

11. О разрешении Наркомздраву РСФСР израсходование средств на реэвакуацию Воронежского и Крымского мединститутов, 19 июля 5 августа 1944 // Государственный архив Российской Федерации (ГАРФ). - Ф. А-259. - Оп. 5. Д. $3088 .-5$ л.

12. Профессора Крымского федерального университета им. В.И. Вернадского : в 3 т. / ред.-сост.: А. А. Непомнящий, Д. А. Ломакин, В. А. Грушецкая [и др.]. - Белгород : Константа, 2018. - Т. 1. - 404 с.

13. Профессора Крымского федерального университета им. В.И. Вернадского : в 3 т. / авт.-сост.: А. А. Непомнящий, Д. А. Ломакин, В. А. Грушецкая [и др.]. - Белгород : Константа, 2018. - Т. 2. -428 с.

14. Профессора Крымского федерального университета им. В.И. Вернадского : в 3 т. / ред.-сост.: А. А. Непомнящий, Д. А. Ломакин, В. А. Грушецкая [и др.]. - Белгород : Константа, 2018. - Т. 3. - 380 с.

15. Профессора Медицинской академии им. С.И. Георгиевского ФГАОУ ВО «КФУ им. В.И. Вернадского», 1918-2016 / авт.-сост.: Н. В. Иванова, Н. Н. Каладзе, Ю. Ю. Сугробова [и др.]. - Симферополь : Н. Орианда, 2016. - 180 с.

\section{REFERENCES}

1. Babanin A.A. Professor B.P. Khvatov-odin iz osnovopolozhnikov Krymskoy morfologicheskoy shkoly [B.P. Puchov - One of the Founders of the Crimean Morphological School]. Tavricheskiy medikobiologicheskiy vestnik, 2002, no. 3, pp. 8-9.

2. Bobin V.V. Vospominaniya o professore Borise Pavloviche Khvatove [Memories About Professor Boris Pavlovich Pachov]. Tavricheskiy medikobiologicheskiy vestnik, 2002, vol. 5, no. 3, pp. 14-15.

3. Ivanova N.V., Kaladze N.N., Sugrobova Yu.Yu., et al. 85 let Meditsinskoy akademii imeni S.I. Georgievskogo Federalnogo gosudarstvennogo obrazovatelnogo uchrezhdeniya «Krymskiy federalnyy universitet imeni V.I. Vernadskogo» [85 Years of S.I. Georgievsky Medical Academy Federal State Educational Institution "V.I. Vernadsky Crimean Federal University”]. Simferopol, N. Orianda Publ., 2016. 180 p.

4. Krivchik A.A., Shishko E.I. Nauchnaya deyatelnost osnovatelya kafedry patologicheskoy fiziologii medfaka BGU professora N.I. Kolpikova: 
k 80-letiyu so dnya rozhdeniya [Scientific Activity of the Founder of the Department of Pathological Physiology of the Medical Department of BSU Professor N.I. Kolpikov: To the $80^{\text {th }}$ Anniversary of Birth]. Otchetnaya nauchnaya konferentsiya Minskogo medinstituta, iyun 1969 g.: tezisy dokladov [Reporting Scientific Conference of Minsk Medical Institute, June 1969: Theses of Reports]. Minsk, Izdvo Minskogo medinstituta, 1969, pp. 132-133.

5. Lisitsa G.I.,Zakharchenko L.Z. V.V. Shostakovich i ukrainskaya psikhiatriya[V.V. Shostakovich and Ukrainian Psychiatry]. Istoriya ukrainskoy psikhiatrii: sbornik nauchnykh rabot Ukrainskogo nauchnoissledovatelskogo instituta klinicheskoy $i$ eksperimentalnoy nevrologii i psikhiatrii i Kharkovskoy gorodskoy klinicheskoy psikhiatricheskoy bolnitsy № 15 (Saburovoy dachi) [History of Ukrainian Psychiatry: Collection of Scientific Works of the Ukrainian Research Institute of Clinical and Experimental Neurology and Psychiatry and Kharkov City Clinical Psychiatric Hospital № 15 (Saburovskaya Dacha)]. Kharkiv, [s. n.], 1994, vol. 1, pp. 102-103.

6. Materialy o deyatelnosti Krymskogo meditsinskogo instituta za 1942 god (otchety, spravki, svedeniya i dr.) [Materials on the Activities of Crimean Medical Institute for 1942 (Reports, References, Information, etc.)]. Gosudarstvennyy arkhiv Rossiyskoy Federatsii (GARF) [State Archive of the Russian Federation], F. A-482, Op. 47, D. 849, 391.

7. Materialy o deyatelnosti Krymskogo meditsinskogo instituta za 1943 g. (otchety instituta ob uchebnoy, lechebnoy, nauchnoy rabote, o khode ekzamenatsionnykh sessiy, protokoly zasedaniy Uchenogo soveta, perepiska instituta s Narkomzdravom RSFSR i t. d.) [Materials on the Activities of Crimean Medical Institute for 1943 (Reports of the Institute on Educational, Therapeutic, Scientific Work, on the Course of Examination Sessions, Minutes of Meetings of the Scientific Council, Correspondence of the Institute with the People's Commissariat of Health of the RSFSR, etc.)]. Gosudarstvennyy arkhiv Rossiyskoy Federatsii $(G A R F)$ [State Archive of the Russian Federation], F. A-482, Op. 47, D. 1671, 951.

8. Materialy o deyatelnosti Krymskogo medinstituta za 1945 god (otchety, plany, svedeniya i dr.) [Materials on the Activities of Crimean Medical Institute for 1945 (Reports, Plans, Information, etc.)]. Gosudarstvennyy arkhiv Rossiyskoy Federatsii (GARF) [State Archive of the Russian Federation], F. A-482, Op. 47, D. 3899, 1561.
9. Nepomnyashchiy A.A., Kravchuk A.S. Istoriya Krymskogo federalnogo universiteta imeni V.I. Vernadskogo $v$ dokumentakh i fotografiyakh [History of V.I. Vernadsky Crimean Federal University in Documents and Photos]. Belgorod, Konstanta Publ., 2018. 352 p.

10. Nepomnyashchiy A.A., Lomakin D.A., Bebeshko E.V. «Rabotali nesmotrya ni na chto»: Krymskiy gosudarstvennyy pedagogicheskiy institut imeni M.V. Frunze v gody Velikoy Otechestvennoy voyny: po materialam fondov Gosudarstvennogo arkhiva Rossiyskoy Federatsii ["Worked Despite of Everything": M.V. Frunze Crimean Teacher Training Institute in Years of the Great Patriotic War: On the Basis of Funds of the State Archive of the Russian Federation]. Uchenye zapiski Krymskogo federalnogo universiteta im. V.I. Vernadskogo. Istoricheskie nauki [Scientific Notes of V.I. Vernadsky Crimean Federal University. Historical Science], 2018, vol. 4 (70), no. 3, pp. 84-105.

11. O razreshenii Narkomzdravu RSFSR izraskhodovanie sredstv na reevakuatsiyu Voronezhskogo i Krymskogo medinstitutov, 19 iyulya 5 avgusta 1944 [On the Permission of the People's Commissariat of Health of the RSFSR to Spend Funds on the Re-Equacation of Voronezh and Crimean Medical Institutions, July 19-August 5, 1944]. Gosudarstvennyy arkhiv Rossiyskoy Federatsii (GARF) [State Archive of the Russian Federation], F. A-259, Op. 5, D. 3088. 51.

12. Nepomnyashchiy A.A., Lomakin D.A., Grushetskaya V.A. et al. Professora Krymskogo federalnogo universiteta im. V.I. Vernadskogo: $v 3 t$. [Professors of V.I. Vernadsky Crimean Federal University. In 3 Vols.]. Belgorod, Konstanta Publ., 2018, vol. 1. 404 p.

13. Nepomnyashchiy A.A., Lomakin D.A. Grushetskaya V.A. et al. Professora Krymskogo federalnogo universiteta im. V.I. Vernadskogo: $v 3 t$. [Professors of V.I. Vernadsky Crimean Federal University. In 3 Vols.]. Belgorod, Konstanta Publ., 2018, vol. 2. 428 p.

14. Nepomnyashchiy A.A., Lomakin D.A. Grushetskaya V.A. et al. Professora Krymskogo federalnogo universiteta im. V.I. Vernadskogo: $v 3 t$. [Professors of V.I. Vernadsky Crimean Federal University. In 3 Vols.]. Belgorod, Konstanta Publ., 2018, vol. 3. 380 p.

15. Ivanova N.V., Kaladze N.N., Sugrobova Yu.Yu. et al. Professora Meditsinskoy akademii im. S.I. Georgievskogo FGAOU VO «KFU im.TV.I. Vernadskogo», 1918-2016 [Professors of S.I. Georgievsky Medical Academy V.I. Vernadsky Crimean Federal University, 1918-2016]. Simferopol, N. Orianda Publ., 2016. 180 p. 


\section{Information About the Authors}

Andrey A. Nepomnyashchiy, Doctor of Sciences (History), Professor, Head of the Department of Historical Regional Studies and Local History, V.I. Vernadsky Crimean Federal University, Prosp. Akademika Vernadskogo, 4, 295007 Simferopol, Russian Federation; Leading Researcher, Crimean Scientific Center of Sh. Marjani Institute of History of the Tatarstan Academy of Sciences, Basenko St., 57, 298405 Bakhchisaray, Russian Federation, dr.aan@mail.ru, https://orcid.org/0000-0002-4031-232X

Dmitriy A. Lomakin, Candidate of Sciences (History), Researcher, Research Center of History and Archaeology of the Crimea, V.I. Vernadsky Crimean Federal University, Prosp. Akademika Vernadskogo, 4, 295007 Simferopol, Russian Federation, LomakinDA@mail.ru, https://orcid.org/0000-0001-8832-4867

\section{Информация об авторах}

Андрей Анатольевич Непомнящий, доктор исторических наук, профессор, заведующий кафедрой исторического регионоведения и краеведения, Крымский федеральный университет им. В.И. Вернадского, просп. Академика Вернадского, 4, 295007 г. Симферополь, Российская Федерация; ведущий научный сотрудник, Крымский научный центр Института истории им. Ш. Марджани АН Республики Татарстан, ул. Басенко, 57, 298405 г. Бахчисарай, Российская Федерация, dr.aan@mail.ru, https://orcid.org/0000-0002-4031-232X

Дмитрий Анатольевич Ломакин, кандидат исторических наук, научный сотрудник Научно-исследовательского центра истории и археологии Крыма, Крымский федеральный университет им. В.И. Вернадского, просп. Академика Вернадского, 4, 295007 г. Симферополь, Российская Федерация, LomakinDA@mail.ru, https://orcid.org/0000-0001-8832-4867 